\title{
Taxation and Leverage in International Banking
}

\author{
Grace Weishi Gu, Ruud de Mooij, \\ and Tigran Poghosyan
}




\title{
IMF Working Paper
}

Fiscal Affairs Department

\section{Taxation and Leverage in International Banking}

\author{
Prepared by Grace Weishi Gu, Ruud de Mooij, and Tigran Poghosyan ${ }^{1}$ \\ Authorized for distribution by Michael Keen
}

November 2012

\begin{abstract}
This Working Paper should not be reported as representing the views of the IMF. The views expressed in this Working Paper are those of the author(s) and do not necessarily represent those of the IMF or IMF policy. Working Papers describe research in progress by the author(s) and are published to elicit comments and to further debate.
\end{abstract}

\begin{abstract}
This paper explores how corporate taxes affect the financial structure of multinational banks. Guided by a simple theory of optimal capital structure it tests (i) whether corporate taxes induce subsidiary banks to raise their debt-asset ratio in light of the traditional debt bias; and (ii) whether international corporate tax differentials vis-a-vis foreign subsidiary banks affect the intra-bank capital structure through international debt shifting. Using a novel subsidiary-level dataset for 558 commercial bank subsidiaries of the 86 largest multinational banks in the world, we find that taxes matter significantly, through both the traditional debt bias channel and the international debt shifting that is due to the international tax differentials. The latter channel is more robust and tends to be quantitatively more important. Our results imply that taxation causes significant international debt spillovers through multinational banks, which has potentially important implications for tax policy.
\end{abstract}

JEL Classification Numbers: $\quad$ G21; G32; H25.

Keywords: Bank taxation; corporate tax; debt bias; leverage. Author’s E-Mail Address: wg62@@cornell.edu; rdemooij@imf.org; tpoghosyan@imf.org.

\footnotetext{
${ }^{1}$ This paper was written during the internship of Grace Weishi Gu at the IMF. We thank Michael Keen for useful discussions, research guidance and invaluable comments on an earlier draft. We also thank Eugenio Cerutti, Abdelhak Senhadji, Hui Tong, and seminar participants at the IMF's Fiscal Affairs Department for helpful suggestions and comments. The usual disclaimer applies.
} 


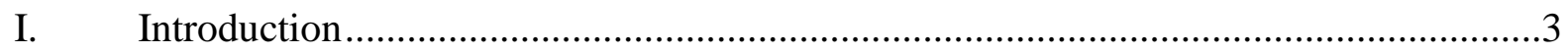

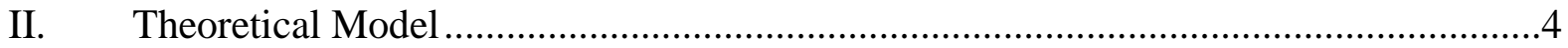

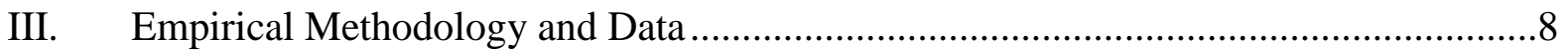

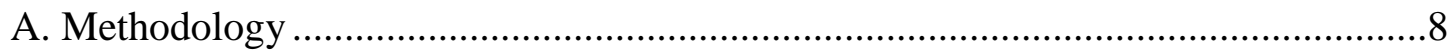

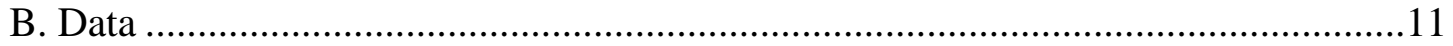

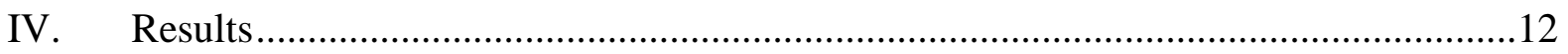

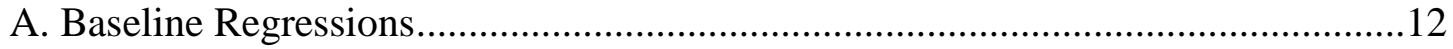

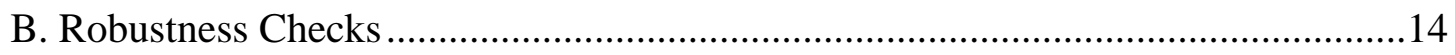

C. Extension: Capital Tightness...................................................................... 16

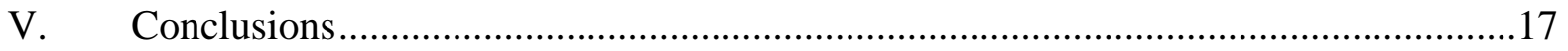

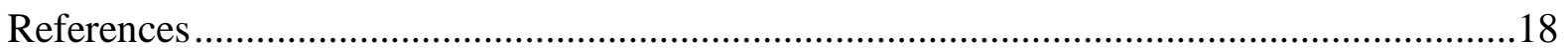

Tables

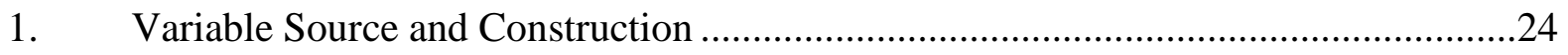

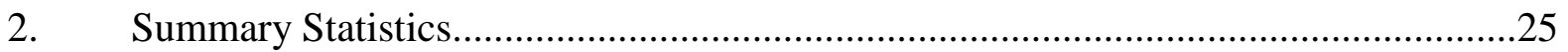

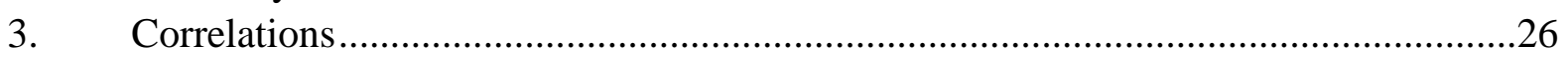

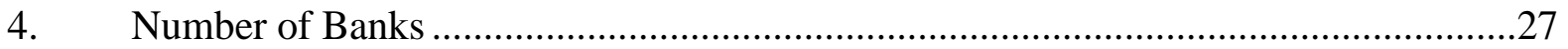

5. Average Financial Leverage and Tax Rates .....................................................28

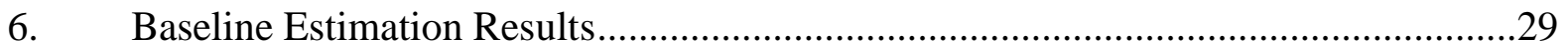

7. Robustness Check Estimation Results: Standard Errors...........................................30

8. Robustness Check Estimation Results: Alternatives ................................................. 31

9. Robustness Check Estimation Results: Leverage Skewness and Tax Trend..............32

10. Robustness Check Estimation Results: Subsamples..............................................33

11. Estimation Results: Capital Tightness ...........................................................34

Figures

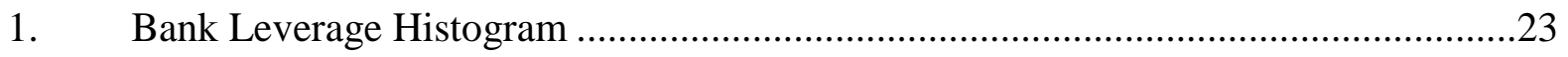

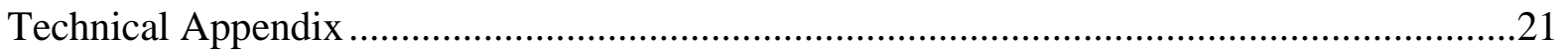




\section{INTRODUCTION}

In most countries, firms can deduct interest expenses from their corporate tax base, but not equity returns. This causes a tax advantage of debt finance, the so-called debt bias of taxation. In the public finance literature, this debt bias has been intensively explored (see e.g. Auerbach, 2002). More recently, the excessive leverage induced by corporate taxation has regained policy interest in the wake of the financial crisis. Indeed, while taxes are unlikely to have caused the crisis, the high indebtedness might have made firms more vulnerable to the negative shock and could well have deepened the crisis.

A large number of studies have empirically estimated the relevance of debt bias and report significant results (see e.g., Graham, 2003, De Mooij, 2011 and Feld and others, 2011). Yet, there are almost no studies on debt bias in the banking sector. Indeed, studies on debt bias either eliminate data on financial firms or make no distinction between financial and nonfinancial companies. Conversely, studies on bank capital structures typically ignore taxation. Only in a recent paper, Keen and De Mooij (2012) analyze debt bias in banks. They point to two special features of banks that can make debt bias different as compared to non-financial firms. First, banks face capital requirements that restrict their debt ratio choice. Second, banks face different agency costs due to regulation (such as deposit insurance), and implicit or explicit state insurance (e.g., due to too-big-to fail status). Using unconsolidated statements of over 14,000 commercial banks in 82 countries, they find that the sensitivity of banks' debt to taxation is very similar to that of non-financial firms. This outcome is important in light of the significant externalities associated with excessive bank leverage. Indeed, high bank leverage tends to increase the probability of a bank's default and, if the bank is systemic, contributes to the probability of a financial crisis. Although Keen and De Mooij (2012) do not look specifically at multinational banks, they do explore whether large banks (which are systemically the most important) differ from small banks and find that the former are notably less responsive to tax.

One strand of the debt bias literature looks into the behavior of multinational firms. Specific for them is the opportunity of international debt shifting. In particular, a multinational can choose the financial structure of its subsidiaries in different countries partly on the basis of tax differences. In a high-tax location, debt finance is attractive because the interest costs can be deducted at a higher rate. In a low-tax location, equity finance is more attractive since the returns will be taxed at a lower rate with the repatriated dividends usually exempt for the parent. Thus, a tax-minimizing strategy will involve relatively more debt in high-tax jurisdictions. Studies for the U.S. by Hines and Hubbard (1990), Collins and Shackelford (1992), Grubert (1998), Altshuler and Grubert (2002), Desai and others (2003), and Mills and

Newberry (2004) all find that subsidiary debt ratios respond to international tax differences in the expected way. For European countries, Moore and Ruane (2005), Huizina and others (2008), Buettner and Wamser (2009), and Egger and others (2010) report similar results. This is an important message since debt shifting erodes corporate tax bases in high-tax countries. 
Several high-tax countries have therefore taken measures to prevent base erosion, for example, by restricting interest deductibility (see e.g., Buettner and others, 2008).

This paper combines the two strands of literature by exploring debt bias in multinational banks. Exploiting a novel dataset for subsidiaries of the 86 largest banks in the world, the analysis aims to shed light on how these banks respond to corporate taxation, including through international debt shifting. The approach is closely related to that in Huizinga and others (2008), who explore debt bias in multinational firms. Their study excludes banks, however. ${ }^{2}$ The analysis of multinational banks in this paper is particularly important for at least two reasons. First, multinational banks are often systemically important, not only within a country but also across countries. Exploring their response to taxation is therefore critical to better understand the causes and consequences of financial crises and the role of taxation therein. Second, it is important to understand the nature and size of international spillovers of tax policy through the banking sector. Indeed, such spillovers raise several policy concerns regarding tax competition, policies to address debt shifting, and interactions with regulation, including through capital requirements.

Using a novel subsidiary-level dataset for 558 commercial bank subsidiaries of the 86 largest multinational banks in the world, we find that taxes matter significantly both through domestic debt bias and international debt shifting. While the tax effects are statistically significant and large, the international debt shifting channel appears to be more robust and tends to be larger than the traditional debt bias. These results imply that taxation causes significant international spillovers through multinational banks, which has potentially important implications for tax policy.

The remainder of the paper is structured as follows. Section II sets out a simple theory to guide our empirical analysis. Section III presents the empirical methodology and data, while Section IV discusses the estimation results. Section V concludes.

\section{THEORETICAL MODEL}

This section develops a model for the optimal capital structure of a multinational bank. It follows the standard trade-off theory in which each subsidiary bank faces a convex non-tax cost of debt finance, e.g., associated with financial distress. At the same time, there is a tax advantage of debt finance since the interest is deductible for corporate taxable profits while equity returns are not. This tax advantage leads the bank to choose a higher leverage, which is traded off against its non-tax cost. In addition to this, the parent bank may decide to

\footnotetext{
${ }^{2}$ Cerutti et al. (2007) argue that the structures of multinational firms and banks are somewhat different. Unlike multinational firms, internationally active banks tend to operate through two types of affiliates: subsidiaries or branches. They show that local corporate taxes affect the mode of bank entry, with branches being a more preferred entry mode in countries that have higher tax rates. We do not consider branches in our empirical analysis and focus on taxation and leverage of subsidiaries.
} 
rebalance the capital structure among its subsidiaries in the host countries where it operates, depending on tax rates. In particular, it will have an incentive to finance subsidiaries in hightax countries by (intra-company) debt since the interest paid is deductible against a high rate. Subsidiaries in low-tax countries will be more likely financed by equity since returns on equity are taxed in the host country and are typically exempt when repatriated to the parent. Thus, the model predicts that the optimal debt-to-assets ratio of a subsidiary bank of a multinational will be positively related to the host country tax rate, as well as to the international tax difference between the host-country tax rate and the tax rates prevailing at other subsidiaries. The model also includes capital requirements, which restrict bank leverage choices. As a subsidiary bank faces tighter capital requirements, the possible legal violation makes it costlier to increase leverage, making it less sensitive to tax changes.

The model extends a simplified version of Albertazzi and Gambacorta (2010) with tax bias from the corporate income tax (CIT) and a convex cost of violating the legal capital requirement. It considers a multinational bank operating in $m$ countries. The multinational has one subsidiary bank ${ }^{3}$ in each host country $i$ with total assets $A_{i}$ assumed to be given. The subsidiary bank provides loans $L_{i}$ yielding an interest rate $l_{i}$, and borrows $B_{i}$ (including deposits and other debts) at interest rate $r$. The profit function for a subsidiary bank $i$ is therefore given by:

$$
P_{i}=l_{i} L_{i}-r B_{i}
$$

which is also the CIT base of the subsidiary bank.

Subsidiary bank $i$ owns fixed assets denoted by $F A_{i}$. Together with the outstanding loans, this forms the asset side of the balance sheet. On the liability side, $E_{i}$ stands for the subsidiary bank's total equity. Hence, the balance sheet constraint of the subsidiary bank is given by:

$$
A_{i}=L_{i}+F A=B_{i}+E_{i}
$$

As in Albertazzi and Gambacorta (2010), we assume that the subsidiary bank is partly owned by the parent of the group and partly by some outside investor. Denoting $k_{i}$ the proportion of the subsidiary bank owned by the outside investor, we assume the required net rate of return by the outside investors to be equal to the return on alternative investment options $(n)$ :

$$
\frac{k_{i} P_{i}\left(1-t_{i}\right)}{E_{i}-F A}-1=n
$$

\footnotetext{
${ }^{3}$ The model does not distinguish between subsidiaries and branches. We assume that the parent bank provides explicit or implicit credit guarantees for the debts of its subsidiaries. If there are multiple subsidiary banks in a country, we consider them as being one subsidiary. In the estimations, we allow multiple subsidiary banks of the same parent in one host country.
} 
The capital structure of both the parent $(p)$ and its subsidiaries $(i)$ are restricted by legal minimum capital requirements $\left(r_{E}\right)$. For subsidiaries, these are set by the country in which the subsidiary operates:

$$
E_{i} \geq r_{E i} L_{i} \text { and } E_{p} \geq r_{E p} L_{p}
$$

The minimum capital requirement in (4) might be violated by either the subsidiary or the parent at a certain legal cost. The parent bank not only takes account of the leverage ratio in its subsidiaries, but also of the leverage of the multinational group as a whole. Thus, we assume that the parent bank provides implicit credit guarantees for the possible bankruptcy and legal penalty in case of violating the capital requirements by its subsidiaries. The total cost of debt finance, caused by both the possible bankruptcy and by the violation of the capital requirement, is denoted by:

$$
\sum_{i=1}^{m} C_{i}+C_{p}
$$

where $C_{i}$ is the total cost of subsidiary bank $i$ and $C_{p}$ the total cost of the parent bank. Similar to Huizinga and others (2008), the cost of the subsidiary is convex and defined as $C_{i}=$ $\frac{m_{i}\left(r_{E i}\right) A_{i} b_{i}^{2}}{2}$. Different from Huizinga and others, the positive parameter $m_{i}\left(r_{E i}\right)$ is an increasing function of the subsidiary's capital requirement, while $b_{i}=B_{i} / A_{i}$ denotes the subsidiary's leverage ratio. Hence, the subsidiary's cost is increasing in its leverage and in the capital requirement. The cost is also convex in leverage and this convexity increases in the capital requirement tightness.

The total cost of the multinational group as a whole is defined as $C_{p}=\frac{g_{p}\left(r_{E p}\right) A_{p}\left(\frac{\sum_{i=1}^{m} B_{i}}{A_{p}}\right)^{2}}{2}$, where $g_{p}\left(r_{E i}\right)$ is a positive and increasing function in the capital requirement faced by the parent bank. The group's total assets are denoted by $A_{p}=\sum_{i=1}^{m} A_{i}$, and the group's total leverage is the sum of all the subsidiaries' debts over the total group assets, i.e., $\frac{\sum_{i=1}^{m} B_{i}}{A_{p}}$. Hence, the parent's total cost is increasing in the group's overall leverage ratio and the capital requirement faced by the parent. Conveniently, we further define each subsidiary's asset share in the group as $q_{i}=\frac{A_{i}}{A_{p}}$, so that we can write $C_{p}=\frac{g_{p}\left(r_{E p}\right) A_{p}\left(\sum_{i=1}^{m} b_{i} q_{i}\right)^{2}}{2}$.

The multinational bank chooses $E_{i}, L_{i}$ and $B_{i}$ so as to maximize its own post-tax profits, i.e., the sum of post-tax profits of all its subsidiaries minus the share that goes to outside investors and minus the total cost from debt finance:

$$
\operatorname{Max} \sum_{i=1}^{m}\left(1-k_{i}\right)\left(1-t_{i}\right) P_{i}-\sum_{i=1}^{m} C_{i}-C_{p}
$$


subject to constraints (1)-(3) and (5). Substituting those into the maximization problem (6) and rearranging yields:

$$
\begin{gathered}
\operatorname{Max} \sum_{i=1}^{m}\left(1-\mathrm{t}_{\mathrm{i}}\right)\left\{L_{i}\left[l_{i}-\frac{1+n}{1-t_{i}}\right]-B_{i}\left[r-\frac{1+n}{1-t_{i}}\right]\right\} \\
-\sum_{i=1}^{m} \frac{m_{i}\left(r_{E i}\right) A_{i} b_{i}^{2}}{2}-\frac{g_{p}\left(r_{E p}\right) A_{p}\left(\sum_{i=1}^{m} b_{i} q_{i}\right)^{2}}{2} .
\end{gathered}
$$

The Technical Appendix derives the first-order conditions of this optimization problem. From the first-order condition of $B_{i}$, we find:

$$
b_{i}=\lambda_{0 i}+\lambda_{1 i} t_{i}+\lambda_{2 i} \sum_{j \neq i}^{m}\left(t_{i}-t_{j}\right) q_{j}+\lambda_{3 i} \sum_{j \neq i}^{m}\left[b_{j}\left(m_{j}\left(r_{E j}\right)-m_{i}\left(r_{E i}\right)\right)\right] q_{j}
$$

where $\lambda_{0 i}=\frac{1+n-r}{g_{p}\left(r_{E p}\right)+m_{i}\left(r_{E i}\right)}, \lambda_{1 i}=\frac{r}{g_{p}\left(r_{E p}\right)+m_{i}\left(r_{E i}\right)}, \lambda_{2 i}=\frac{g_{p}\left(r_{E p}\right) \mathrm{r}}{m_{i}\left(r_{E i)}\left[g_{p}\left(r_{E p}\right)+m_{i}\left(r_{E i}\right)\right]\right.}$, and $\lambda_{3 i}=$ $\frac{g_{p}\left(r_{E p}\right)}{m_{i}\left(r_{E i}\right)\left[g_{p}\left(r_{E p}\right)+m_{i}\left(r_{E i}\right)\right]}$.

Equation (8) shows that the leverage ratio of a subsidiary bank depends on two tax-related terms. First, the term $\lambda_{1 i} t_{i}$ reflects the impact of what we call 'local' taxation, which refers to the tax rate in the country where the subsidiary resides. The coefficient $\lambda_{1 i}$ should be positive, indicating that a higher local CIT rate will increase bank leverage. This first effect measures the traditional debt bias induced by the CIT. Second, the term $\lambda_{2 i} \sum_{j \neq i}^{m}\left(t_{i}-t_{j}\right) q_{j}$ reflects the impact of international tax differences. The coefficient $\lambda_{2 i}$ is positive, suggesting that as the CIT in the subsidiary country becomes relatively high compared to CIT rates in other subsidiary countries, the leverage ratio in the subsidiary bank rises. It thus measures international debt shifting. Important for our empirical analysis is that in the second term the international tax differences $\left(t_{i}-t_{j}\right)$ are weighted by the asset shares $q_{j}$ of subsidiaries in all the other host countries.

The tax impact in (8) depends on the capital requirements faced by both subsidiaries and the parent bank. This impact is captured by the parameters $\lambda_{1 i}$ and $\lambda_{2 i}$. In particular, when the capital requirement becomes tighter, i.e., $r_{E i}$ gets larger, this raises the legal cost at the margin of holding debt. The higher marginal cost of raising leverage makes the bank less sensitive to tax changes. In the regressions, we will test whether this assumption is indeed validated.

The theory also offers some insights on the relative magnitudes of $\lambda_{1 \mathrm{i}}$ and $\lambda_{2 \mathrm{i}}$, which measure the importance of the local tax as compared to the international tax differential. In particular, 
if $g_{p}\left(r_{E p}\right)>m_{i}\left(r_{E i}\right)$, i.e., if the cost associated with debt finance is larger for the parent bank than for subsidiary bank, then $\lambda_{1 \mathrm{i}}<\lambda_{2 \mathrm{i}}$. In that case, the international tax difference exerts a larger effect on the debt ratio than the local tax. This assumption requires that the cost of financial leverage is larger for the multinational group as a whole as compared to that for a subsidiary. Intuitively, the parent bank will then find it relatively easy to shift debt across subsidiary banks, but more costly to modify the overall debt level of the group. However, if debt finance would be less costly for the multinational group as a whole compared to subsidiary banks, e.g., because unlike the parent bank, the subsidiaries do not enjoy the same protection against bank failure, then the opposite would hold. In the next section, we will explore these effects empirically.

Summing up, the main predictions of the model are as follows:

1. Bank leverage depends positively on the local CIT rate.

2. Bank leverage depends positively on the difference between the subsidiary's own country's CIT rate and that of other subsidiary countries. The CIT rates in other subsidiaries should be weighted by asset shares.

3. The impact of the local tax might be either smaller or larger than the impact of the international tax difference, depending on the marginal cost of financial leverage in the subsidiary versus the parent bank.

4. As a host country's capital requirement becomes tighter, ceteris paribus, its bank leverage becomes less sensitive to tax changes.

\section{EMPIRICAL METHOdOlOGY AND DATA}

\section{A. Methodology}

The strategy is to estimate a series of panel regressions of the general form:

$$
\text { leverage }_{i k t}=\alpha+\lambda_{1} \operatorname{tax}_{i t}+\lambda_{2} i t d_{i t}+\beta \sigma_{i k t}+\delta \gamma_{i t}+\mu_{i}+\varepsilon_{i k t}
$$

where leverage $e_{i k t}$ is total liability/assets ratio for subsidiary bank $k$ in subsidiary host country $i$ in year $t, \operatorname{tax}_{i t}$ is the statutory corporate income tax (CIT) rate the subsidiary bank faces, $i t d_{i t}$ is a variable measuring international tax difference (see below), $\sigma_{i k t}$ is a vector of bank-level controls, $\gamma_{i t}$ is a vector of subsidiary host country-level controls, and $\mu_{i}$ is subsidiary host country fixed effect. Attention focuses on the coefficients $\lambda_{1}$ and $\lambda_{2}$, which reflect the marginal impacts of, respectively, the local CIT rate faced by the subsidiary bank and the international CIT difference. In particular, the theory predicts that $\lambda_{1}>0$ and $\lambda_{2}>0$. Also, the tax elasticity of leverage is expected to be larger if a bank holds more capital 
beyond the capital requirement it faces (i.e., $\lambda_{1}$ and $\lambda_{2}$ become smaller for banks with a higher debt ratio relative to the one induced by the legal capital requirement).

The measurement of international tax difference is the weighted average of differences between the subsidiary host country's tax rate and those of other subsidiaries of the same parent, as in Huizinga and others (2008). More specifically, it is computed as $\sum_{j \neq i}^{m}\left(\operatorname{tax}_{i t}-\right.$ $\left.\operatorname{tax}_{j t}\right) q_{j t}$, where the parent bank has a total of $m$ subsidiary banks, and weights $q_{j t}$ reflect their shares in the total assets of the multinational group, $q_{j t}=\frac{A_{j t}}{\sum_{m} A_{j t}}$. A positive value of this tax difference variable indicates that, on average, there is an incentive to shift debt into the subsidiary host country; a negative value indicates the opposite.

To understand the calculation of the international tax difference variable, let us illustrate it with an example. Suppose there is a corporate group that consists of three $(m=3)$ subsidiaries $\mathrm{A}, \mathrm{B}$, and $\mathrm{C}$, each having one third of total assets. The international tax difference for subsidiary $\mathrm{A}, i t d_{A}$, is then calculated as the asset-weighted differences between the tax rate applicable to $\mathrm{A}, \tau_{A}$, and the tax rates applicable to $\mathrm{B}$ and $\mathrm{C}, \tau_{B}$ and $\tau_{C}$, respectively: $i t d_{A}=$ $\sum_{j \neq A}^{m}\left(\tau_{A}-\tau_{j}\right) q_{j}=\left(\tau_{A}-\tau_{B}\right) \frac{1}{3}+\left(\tau_{A}-\tau_{C}\right) \frac{1}{3}$. If $\tau_{A}$ is 10 percent, and both $\tau_{B}$ and $\tau_{C}$ are 20 percent, then $i t d_{A}$ equals -7 percent. As subsidiary $A$ is located in a low-tax country, there exists an incentive to decrease leverage in subsidiary A. If $\tau_{A}$ increases to 50 percent, itd $A$ would rise to 20 percent and subsidiary A would be located in a high-tax country, implying an incentive to increase leverage in subsidiary A.

The size of a subsidiary matters for debt shifting. Suppose subsidiary A's asset size increases to one half of the group's assets, while $B$ and $C$ are still of equal size. We assume that $\tau_{A}$ is 50 percent, while $\tau_{B}$ and $\tau_{C}$ are 20 percent. The international tax difference is now: $i t d_{A}=$ $\left(\tau_{A}-\tau_{B}\right) \frac{1}{4}+\left(\tau_{A}-\tau_{C}\right) \frac{1}{4}=15$ percent instead of 20 . Hence, the weighted international tax difference is smaller than in the previous example. More generally, the larger is a subsidiary in terms of total assets of the multinational group, the smaller will be the impact of a tax change through debt shifting. Intuitively, the debt shifting channel is proportional to the size of foreign subsidiaries. The smaller the assets held by subsidiary banks abroad, the smaller the scope for debt shifting. Likewise, debt shifting is proportionally larger for a small subsidiary.

We can rewrite the international tax difference as: $\sum_{j \neq i}^{m}\left(\operatorname{tax}_{i t}-\operatorname{tax}_{j t}\right) q_{j t}=\operatorname{tax}_{i t}-$ $\sum_{i}^{m} \operatorname{tax}_{i t} q_{i t}$. The latter term reflects the tax difference between the subsidiary and the weighted average tax rate of the group as a whole (or: the average tax faced by the parent bank). Since it contains the tax level variable $\operatorname{tax}_{i}$ captured by the second term on the righthand side of (10), we can also estimate one coefficient for the sum of $\lambda_{1}$ and $\lambda_{2}$, and then separately estimate $\lambda_{2}$ for the second term $\sum_{i}^{m} \operatorname{tax} i t q_{i t}$. In the regressions, we also use alternative weights in the measurement of the international tax difference, such as a time- 
invariant asset weights instead of the year-by-year asset weights (to eliminate a possible endogeneity problem arising from endogenous assets) and leverage weights.

The bank-level controls in $\sigma_{i k t}$ are those usually included in the capital structure literature (for example, Rajan and Zingales, 1995, and Frank and Goyal, 2009). First, we include the book value of a bank's assets and its square to allow for non-linear size effect. This scaling variable reflects that larger banks may have easier access to credit because they tend to be more diversified and less prone to bankruptcy (Rajan and Zingales, 1995). Moreover, larger banks may benefit from a too-big-to-fail notion (for example, De Haan and Poghosyan, 2011). Thus, we expect a positive relationship between bank size and its leverage.

Second, we include the pre-tax return on assets as a measurement of profitability. Theory suggests that this effect is ambiguous. On the one hand, profitable banks may be perceived to be less risky and face less financial distress, which would facilitate their access to external credit. Moreover, profitable banks may have more incentive to reduce tax payment by raising debt than loss-making banks that benefit less from its deductibility. This would suggest a positive relationship between profitability and leverage. On the other hand, higher profits add to equity when retained within the firm, directly reducing the leverage ratio. This would suggest a negative relationship between profitability and leverage. This is also consistent with the "pecking order" theory developed by Myers and Majluf (1984), according to which in the presence of asymmetric information firms prioritize internal financing to the issuance of new equity.

Third, growing banks invest more, holding profitability constant and should accumulate more debt over time. However, growth also decreases financial distress and places a greater value on the equity holder, thereby encouraging equity investment and reducing leverage. Overall, its effect on leverage is ambiguous. In terms of the measurement of bank growth, market-tobook asset ratio is the most commonly used proxy. But since not all subsidiary banks in our sample are listed, we use total book assets growth.

Fourth, collateral can reduce costs of issuing both debt and equity. In capital structure regressions for non-banks, it is typically found that collateral increases access to external funding so that firms need to rely less on retained earnings. Thus, the leverage ratio tends to rise. The very nature of the banking sector and the impact of regulation may change this for banks, however. We use the proportion of total security assets and non-earning assets out of total assets as a proxy for collateral.

Finally, DeAngelo and Masulis (1980) show that non-debt tax shields are a substitute for the tax benefits of debt financing. Hence, they should be negatively related to leverage. We measure non-debt tax shields by total non-interest expenses to total assets ratio. 
We also control for subsidiary host country determinants. First, we include GDP growth and inflation. High growth at the country level is expected to facilitate debt finance. An inflationary environment may lead to higher risk premiums and discourage debt supply. Yet, as nominal interest is deductible for the CIT, high inflation may also encourage debt finance as it lowers real borrowing costs. On balance, the impact of inflation on leverage is ambiguous. Second, if a country provides generous deposit insurance, depositors may be more willing to place their funds in banks without having to monitor their activities. We include a 0/1 dummy for the existence of deposit insurance and expect its impact to be positive. Third, we include the minimum capital requirement, which should have a negative impact on leverage. Finally, we add a financial crisis dummy from Laeven and Valencia (2010). A crisis may initially increase the leverage ratio due to the decline in equity values, but may subsequently reduce leverage.

\section{B. Data}

Data of the 100 largest multinational banks in the world are taken from the Bankscope database, compiled by Bureau Van Dijk. It provides accounting data on banks around the world, including information about ownership relationships. This latter information allows us to match multinational parents with their domestic and foreign subsidiaries. ${ }^{4}$ In our analysis, we focus on commercial banks and we do not consider branches. We define a bank as a subsidiary if more than 50 percent of its shares are owned by the parent bank. Multinational banks typically provide both consolidated and unconsolidated accounting statements. The consolidated statements reflect the activities of the parent banks themselves and all subsidiaries they own. The unconsolidated statements, in contrast, reflect only the accounts of each bank, either parent or subsidiary. In our regressions, we use only data of subsidiaries, not those of the parents. If a subsidiary bank owns other subsidiaries, then its accounts may be either consolidated or unconsolidated. In our data, 36 percent of the subsidiaries report consolidated accounts and 64 percent report unconsolidated statements.

Table 1 shows detailed information about variables and data sources. Starting from the raw data, we first drop all inactive subsidiary banks and subsidiary banks with a leverage ratio larger than 99 percent. We also drop subsidiary banks with a pre-tax profit-to-asset ratios smaller than -20 percent or larger than 250 percent, those with negative total non-interest expenses, non-earning assets-to-total assets ratio larger than 99 percent, total assets growth larger than 150 percent, effective tax rates smaller than zero, and missing total assets and CIT rates. Doing so, we end up with a sample of 558 subsidiary banks (both domestic and foreign), owned by the 86 largest commercial banks in the world. The parents are headquartered in 25 countries, while subsidiaries are located in 66 host countries. The sample

\footnotetext{
${ }^{4}$ Bankscope does not report historical ownership information. Therefore, our analysis is based on the latest ownership information, implicitly assuming that ownership has not changed for banks in our sample. A robustness check based on the data for last two years yields qualitatively similar results on the impact of taxes, providing indirect support to this assumption.
} 
spans through the 1998-2011 period. Table 2 provides summary statistics of main variables of interest, such as leverage, statutory CIT rates, international tax differences, and control variables. Table 3 displays the correlations among variables. Figure 1 shows the distribution of bank leverage in the sample.

Table 4 shows information on the number of parent banks and subsidiaries, both domestic and foreign, in different countries. We see that many parents reside in France, Germany, Spain, the U.K., and the U.S. A relatively large number of subsidiaries are hosted in France, Luxemburg, Russia, the U.K., and the U.S. Table 5 provides information on financial leverage and tax rates in subsidiary countries. The average financial leverage ranges from 69.3 percent in Argentina to 94.9 percent for Spain. CIT rates for subsidiaries are the highest in Japan and the lowest for Bosnia and Herzegovina. The international tax difference variable suggests that subsidiaries in Germany, Thailand, and Zambia should have the largest debt levels in light of their high tax, while subsidiaries in Albania, Bosnia and Herzegovina, and Ireland, should have the lowest debt ratios.

\section{RESUlTS}

Table 6 reports our baseline results, where we regress subsidiary bank leverage on tax variables and bank-level variables, first without and then with country-level variables. Tables 7-10 show various robustness checks, using alternative estimators, samples and specifications. Finally, Table 11 partitions observations by capital tightness.

\section{A. Baseline Regressions}

Results in Table 6 are based on OLS regressions with subsidiary host country fixed effects. For each variable we indicate between brackets the predicted sign of the coefficient.

Regression (1) contains local tax level and bank-level variables, excluding international tax difference variables and host country controls. We see that the local tax coefficient is close to 0.3 and statistically significant. It supports hypothesis (1), namely that a higher tax in the subsidiary's host country increases the debt ratio. The coefficient of 0.3 means that an increase in the statutory CIT rate by 10 percentage points will increase the leverage ratio by 3 percentage points $(=0.3 \times 10)$. The size of the effect is close to the coefficient of 0.26 found for non-financial firms in Huizinga and others (2008), and in the meta analysis of De Mooij (2011). It is also very similar to the coefficient of 0.27 for banks found by Keen and De Mooij (2012).

Bank-level control variables are also important. Table 6 confirms that larger banks have higher leverage ratios. Higher profitability reduces the leverage ratio. While theory is ambiguous about the impact of bank growth on leverage, our estimations suggest that faster growing banks accumulate more debt. The collateral variable has a negative coefficient, again consistent with that for non-financial firms (Huizinga and others, 2008). While collateral is generally expected to have a positive effect on financial leverage, it can also 
make equity issuance less costly with lower asymmetric information (Rajan and Zingales, 1995). Apparently for our sample this positive impact on equity appears to be dominant. Finally, non-debt tax shields tend to substitute for the tax benefits of debt financing and reduce leverage, as suggested by DeAngelo and Masulis (1980).

Regression (2) adds the international tax difference. We see that the estimated coefficient for this variable is statistically significant and positive. It supports the theory that leverage at any subsidiary bank is affected by the international tax differences faced by the corporate group as a whole, consistent with our hypothesis (2). Note that the local CIT rate enters both in the first and in the second term. The first term, measured by the coefficient $\lambda_{l}$, indicates the effect of local taxation on the leverage of banks (local tax channel). We see that this effect is smaller than in the first regression, which is because part of the impact is now captured by the second term. With a coefficient of 0.25 , however, the impact remains sizeable. The second term, measured by the coefficient $\lambda_{2}$, captures the international tax difference or international debt shifting effect on leverage (international tax difference channel). The coefficient of 0.12 suggests that the local tax exerts an additional impact, over and above the local tax channel. The size of this effect is smaller, however, than the first channel.

Regressions (3) and (4) augment regressions (1) and (2) with a set of additional host countrylevel controls. The GDP growth variable enters the regressions positively, as expected. However, all other host country controls are not statistically significant, except that in column (4) the financial crisis variable enters with a weakly significant negative coefficient. The estimated coefficient for the CIT rate in regression (3) is very similar to that in column (1), although slightly smaller in size. It again confirms hypothesis (1). In regression (4) the estimated coefficient for the local CIT is reduced to 0.16 , quite a bit smaller than in column (2). The coefficient for the international tax differential is positive and significant, consistent with hypothesis (2). Compared to column (2) the coefficient is somewhat larger at 0.18. Comparing the two tax channels in column (4), we see that the local tax coefficient is slightly smaller than the coefficient for the international tax difference. This would be consistent with the case whereby the marginal cost of higher leverage for the multinational group is larger than that for a single subsidiary. The difference is not statistically significant, however (the F-test of coefficient equality has p-value of 0.69). Hence, column (4) suggests that the local tax channel and the international debt shifting are both relevant in explaining the impact of the CIT on the leverage ratio of subsidiary banks.

To illustrate the findings in columns (3) and (4) further, we use an example of a hypothetical U.S. multinational bank. On average, in our sample a U.S. multinational bank has about 10 subsidiaries around the world. Suppose now that our hypothetical U.S. parent bank owns 10 subsidiaries, each with equal asset size. We consider a tax cut in country A where one of the subsidiaries resides by 10 percentage points, while keeping the tax rates in all other countries unchanged. In that case, there are two channels through which the leverage ratio in the subsidiary bank in country $\mathrm{A}$ is affected. If we use the results in regression (3), the two 
effects are combined and measured by the coefficient of the CIT rate. The 10 percent rate reduction will reduce the leverage ratio in the subsidiary by 2.5 percent. If we use regression (4), the local tax channel and the international debt shifting channel are separated. Through the first channel, we see that the leverage ratio drops by 1.59 percentage points. Through the second channel, the leverage ratio declines by 1.62 percentage points $(=0.18 \times 10 \times 0.9)$. The overall impact is thus 3.21 percentage points $(=1.59+1.62)$. Suppose next that the statutory CIT rate declines by 10 percentage points in all countries, except for country A. In regression (3) there is no effect on leverage since foreign tax rates are not included in the regression and international debt shifting cannot be measured explicitly. In regression (4), however, the international tax difference rises by 9 percent $(=0.9 \times 10$ percent $)$. This increases the leverage ratio in the subsidiary bank in country A by 1.62 percentage points $(9 \times 0.18)$. Hence, international spillovers associated with multinational debt shifting can only be captured by regression (4).

The results in Table 6 suggest significant and sizeable effects of taxation on bank leverage. If we look at the size of the subsidiary banks in the data, the mean value of total assets is USD 2.8 billion while the median is USD 2.1 billion. This is larger than the banks analyzed in Keen and De Mooij (2012). In their data, only 5 percent of the banks exceed an assets size of USD 1.2 billion. While Keen and De Mooij find very small tax responses for this 5 percent group of largest banks, our sample containing relatively large banks reports considerably larger effects. In column (4), we see that a considerable part of this effect originates from international debt shifting. Hence, our results suggest that large subsidiary banks are as responsive as the average found in Keen and De Mooij (2012), but that the impact on debt is for more than half explained by international debt shifting.

\section{B. Robustness Checks}

Tables 7-10 present robustness checks, taking regression (4) in Table 6 as the benchmark specification. In Table 7 regressions (5)-(7) correct standard errors by clustering observations across parent banks, host countries, and subsidiaries, respectively. The estimated coefficients for the two tax variables are unchanged by this clustering, but standard errors increase. Nevertheless, the tax coefficients remain statistically significant at either the 1 percent or 5 percent level. Regression (8) uses the Driscoll and Kraay (1998) standard errors, which are robust to heteroskedasticity and autocorrelation in the error structures up to some lag (or where errors are correlated between groups). Again, the local tax variable remains statistically significant at the 5 percent level, but the international tax difference loses significance, now only significant at 10 percent.

In Table 8 regressions (9)-(11) adopt alternative measurements for the international tax difference channel. Given that the construction of international tax difference variable includes an element of the local tax rate, it is highly correlated with local tax variable (with a correlation coefficient of 0.68 in Table 3). In regression (9) we exclude the local tax rate 
from the second term. Thus, the coefficient for the CIT rate captures the overall impact of a change in taxation on subsidiary leverage, both through domestic leverage and international debt shifting. The coefficient for the international tax captures only the foreign tax rates, reflecting international debt shifting. As expected, regression (9) shows that (i) the coefficient for the CIT rate is now larger (reflecting both channels), and (ii) the foreign tax has a negative coefficient: higher foreign taxes tend to reduce leverage of the subsidiary itself. In fact, the coefficient of the foreign tax variable is the same as in the regression (4), except that now $\lambda_{1}{ }^{\prime}=\lambda_{1}+\lambda_{2}$ and $\lambda_{2}{ }^{\prime}=-\lambda_{2}$.

Regression (10) eliminates the time variation in asset weights by using constant asset weights in the calculation of the weighted average foreign tax rate. The constant asset weights are calculated as the average of the asset weights across time for each subsidiary bank. This may help to reduce potential endogeneity issues arising from endogenous assets. ${ }^{5}$ The coefficients remain significant in this regression for our two core tax variables. In fact, the international tax difference tends to become larger, while the local tax variable becomes smaller. In column (11) we use leverage shares rather than asset shares to determine the international tax difference variable. The results are very similar to those in column (4) of Table 7. Finally, regression (12) takes short-term debt as the dependent variable rather than total leverage. Short-term debt is calculated as total leverage minus long-term funding. While both tax variables enter again with a positive coefficient, the local tax coefficient is larger than before, implying that long-term debt (such as customer saving deposits) is less responsive to tax than short-term liabilities. Interestingly, regression (12) shows that the deposit insurance variable reduces short-term debt. Together with an insignificant coefficient for total leverage, it suggests that deposit insurance exerts a positive effect on long-term funding. This is intuitively appealing as the debt covered by deposit insurance tends to be of a long-term nature.

In Table 9 regression (13) adopts quantile regression instead of OLS to addresses the possible impact of the skewed distribution of bank leverage. Usually, quantile regressions approximate the conditional median instead of the mean of the dependent variable, which reduces the impact of outliers. Thus, estimates should be more robust, especially if the response measurements are highly skewed. Figure 1 shows that the distribution of bank leverage in our sample is indeed highly skewed to the right tail. Regression (13) suggests that the tax effects remain statistically significant, as before, but the magnitudes become smaller. As quantile regressions give less weight to sample outliers, this might be expected. It suggests, however, that outliers are important for estimated effect sizes in the earlier regressions. Regression (14) in Table 9 contains a trend variable by host country. This may capture the declining trend in statutory CIT rates worldwide. We see that the local tax

\footnotetext{
${ }^{5}$ We also ran regressions for a dynamic specification using the system GMM estimator as in Keen and De Mooij (2012). The instruments should help to reduce possible endogeneity. However, the results turned out to be very sensitive to the choice of instruments and are therefore not reported.
} 
variable now becomes statistically insignificant, but the international tax difference variable remains significant and large.

Table 10 explores the regression as in (4) but for various subsamples. In regression (15) we restrict the sample to subsidiaries for which we have unconsolidated data. This reduces the number of observations from 3905 to 2569 . The results for core tax variables are very much the same, although the impact of the international tax difference is larger than before. Regression (16) considers only subsidiary banks with positive profits. One may expect taxes to have a larger effect for profitable banks, since the value of interest deductions are smaller for loss-making banks (as costs can only be used against future profits, if at all). The coefficients for $\lambda_{1}$ and $\lambda_{2}$ are indeed larger than the ones in the baseline estimation, which provides some support for this. Regression (17) limits the sample to subsidiaries in advanced countries. The latter are defined as countries where the domestic credit provided by the banking sector as a share of GDP is higher than the sample average. We expect the debt shifting channel to be more pronounced in these countries where banks use more sophisticated products that could facilitate international debt shifting. Indeed, relative to the benchmark regression, the value of $\lambda_{2}$ is much larger in magnitude at 0.47 instead of 0.18 . However, we find no significant effect of the local tax rate. Note that regression (17) also reports a positive impact of inflation on leverage and a negative impact of capital requirements. ${ }^{6}$ Finally, regression (18) confines the sample to the period before the current global recession and excludes observations between 2009-2011. The tax effects are similar to the baseline estimates, with a larger coefficient for the international tax difference. Now, we see that inflation is negatively associated with bank leverage.

\section{Extension: Capital Tightness}

Section II assumes that banks that are tight in capital relative to the legal capital requirement are less responsive to tax. The reason is that a violation of the capital requirement would cause a convex legal cost. Capital-tight banks, i.e., those that are close to the capital requirement, will be more constrained in adjusting leverage ratios. The conjecture is therefore that the responsiveness to tax declines with the capital ratio, relative to the minimum capital requirement. To test this hypothesis, we calculate capital tightness as follows. For each subsidiary bank we take its capital relative to the legal capital requirement prevailing in the country. We then divide subsidiary banks into three equal-sized groups: banks with most abundant capital, an intermediate group, and a group of banks with the tightest capital. We run regressions for both the group with most abundant capital and the tightest capital. The results are reported in Table 11. Comparing columns (19) and (20) we

\footnotetext{
${ }^{6}$ For deposit insurance there is weakly significant negative coefficient. This contrasts expectations. However, it might be that in the absence of deposit insurance governments in advanced countries offer implicit insurance to banks, e.g., through the expectation of public bail out at times of distress. Hence, the presence of explicit deposit insurance may capture lower insurance through other channels, consistent with the finding of Gropp and Vesala (2001).
} 
see that taxes exert a larger impact on the leverages of the capital-abundant banks. Indeed, the coefficients for the local tax and the international tax difference are, respectively, 0.28 and 0.35. For capital-tight banks, however, the coefficients are 0.05 and -0.02 , respectively, whereby the latter is statistically insignificant. Hence, if the host country's capital requirement becomes tighter, we expect banks to become less sensitive to tax changes. This is consistent with our theoretical hypothesis (3) and also with the findings in Keen and De Mooij (2012).

\section{Conclusions}

This paper analyzes the sensitivity of multinational bank capital structures to taxation. Using a sample of 558 bank subsidiaries over 1998-2011, we find that a bank's leverage ratio depends on corporate taxes in two ways: (i) the traditional form of debt bias, measured by the local tax rate in the host country of the subsidiary; and (ii) international debt shifting, measured by the international tax difference vis-a-vis other bank subsidiaries in the same group. While the tax effects are statistically significant and large, the international debt shifting channel appears to be more robust and is often larger in the regressions than the traditional debt bias. It implies that tax policy induces significant international spillovers through its impact on multinational bank behavior.

The results raise a number of policy concerns. First, international spillovers may intensify the incentives for tax competition by governments, which may lead to inefficient policies. It could strengthen the case for international tax coordination. Second, countries may seek measures to remedy international debt shifting - such as, by imposing thin capitalization rules that restrict the deductibility of interest on intracompany loans. These measures, however, generally do not apply to banks and raise the issue of specific bank regulation or bank taxation. More fundamentally, countries may consider eliminating debt bias altogether by neutralizing the tax treatment of debt and equity, e.g., by introducing an allowance for corporate equity - as Belgium, Italy, and Latvia have done. In principle, such an allowance could be applied specifically to the banking sector alone. Finally, capital requirements may play a role for the impact of taxation. The results in this study, for instance, suggest that banks become less responsive to tax if their equity is closer to the minimal capital requirement. The interaction of taxation and regulation is thus important for developing appropriate policy responses to debt bias. 


\section{REFERENCES}

Auerbach, A.J., 2002, Taxation and Corporate Financial Policy in Alan J. Auerbach and Martin Feldstein (eds.), Handbook of Public Economics Vol. 3, pp. 1251-92 (Amsterdam, Elsevier North-Holland).

Albertazzi, U., and L. Gambacorta, 2010, Bank Profitability and Taxation, Journal of Banking and Finance, 34(11), pp. 2801-10.

Altshuler, R., and H. Grubert, 2002, Repatriation Taxes, Repatriation Strategies, and Multinational Financial Policy, Journal of Public Economics, 87, pp. 73-107.

Bankscope, online June $4^{\text {th }}, 2012$ at https://bankscope2.bvdep.com/version2012713/Search.QuickSearch.serv?_CID=1\&context=2QGD7U3339HXXS6

Buettner, T., and G. Wamser, 2009, Internal Debt and Multinationals' Profit Shifting: Empirical Evidence from Firm-level Panel Data, Working Paper 0918, Oxford.

Cerutti, E., Dell'Ariccia, G., and M. S. Martinez Peria, 2007, How Banks Go Abroad: Branches or Subsidiaries?, Journal of Banking and Finance, 31, pp. 1669-92.

Collins, J.H., and D. Shackelford, 1992, Foreign Tax Credit Limitations and Preferred Stock Issuance, Journal of Accounting Research, 30, pp. 103-24.

DeAngelo, H., and R. Masulis, 1980, Optimal Capital Structure under Corporate and Personal Taxation, Journal of Financial Economics, 8, pp. 3-29.

de Haan, J., and T. Poghosyan, 2011, Bank Size, Market Concentration, and Bank Earnings Volatility in the U.S., Journal of International Financial Markets, Institutions and Money, 22, pp. 35-54.

de Mooij, R.A., 2011, Taxes Elasticity of Corporate Debt: A Synthesis of Size and Variations, IMF Working Paper 11/95 (Washington: International Monetary Fund).

Driscoll, J.C., and A.C. Kraay, 1998, Consistent Covariance Matrix Estimation with Spatially Dependent Panel Data, Review of Economics and Statistics, 80, 549-60.

Egger, P., W. Eggert, C. Keuschnigg, and H. Winner, 2010, Corporate Taxation, Debt Financing and Foreign-plant Ownership, European Economic Review, 54, pp. 69-107.

Feld, L.P., J. Heckemeyer, and M. Overesch, 2011, Capital Structure Choice and Company Taxation: A Meta-study, CESifo Working Papers No. 3400. 
Frank, M., and V. Goyal, 2009, Capital Structure Decisions: Which Factors are Reliably Important? Financial Management, 38, pp. 1-37.

Graham, J.R., 2003, Taxes and Corporate Finance: A Review, Review of Financial Studies, 16, pp. 1075-1129.

Gropp, R. and F. Heider, 2009, The Determinants of Bank Capital Structure, European Central Bank Working Paper, No. 1096.

and J. Vesala, 2001, Deposit Insurance and Moral Hazard: Does the Counterfactual Matter? ECB Working Paper No. 47, March.

Grubert, H., 1998, Taxes and the Division of Foreign Operating Income among Royalties, Interest, Dividends and Retained Earnings, Journal of Public Economics, 68, 269290.

Hines, J.R., and R.G. Hubbard, 1990, Coming Home to America: Dividend Repatriation by U.S. Multinationals, in Razin, A. and R.G. Hubbard (Eds.), Taxation in the Global Economy, (Chicago: University of Chicago).

Huizinga, H., L. Laeven, and G. Nicodeme, 2008, Capital Structure and International Debt Shifting, Journal of Financial Economics, 88, pp. 80-118.

IMF, A Fair and Substantial Contribution by the Financial Sector: Final Report for the G-20, June, 2010 (Washington: International Monetary Fund).

, World Economic Outlook (WEO), online June $4^{\text {th }}, 2012$ at http://www.imf.org/external/pubs/ft/weo/2012/01/weodata/index.aspx (Washington: International Monetary Fund).

Keen, M., and R.A. de Mooij, 2012, Debt, Taxes and Banks, IMF Working Paper 12/48 (Washington: International Monetary Fund).

KPMG, Corporate Tax Survey, 1993-2012.

Laeven, L., and F. Valencia, 2010, Resolution of Banking Crises: The Good, the Bad, and the Ugly, IMF Working Paper 10/146, Banking Crisis Database (2010 version).

Mills, L.F., and K.J. Newberry, 2004, Do Foreign Multinationals' Tax Incentives Influence Their U.S. Income Reporting and Debt Policy? National Tax Journal, 57, pp. 89-107. 
Mintz, J., and A.J. Weichenrieder, 2009, Indirect Side of Direct Investment: Multinational Company Finance and Taxation (Cambridge, Massachusetts: MIT Press).

Moore, P.J., and F.P. Ruane, 2005, Taxation and the Financial Structure of Foreign Direct Investment, IIIS Discussion Paper No. 88, Dublin.

Myers, S., and N. Majluf, 1984, Corporate Financing and Investment Decisions when Firms Have Information that Investors do not Have. Journal of Financial Economics, 13, $187-221$.

OECD Tax Database, available online June $4^{\text {th }}, 2012$ at http://www.oecd.org/document/60/0,3746,en_2649_34533_1942460_1_1_1_1,00.ht $\underline{\mathrm{ml}}$

Rajan, R.G., and L. Zingales, 1995, What Do We Know About Capital Structure? Some Evidence from International Data, Journal of Finance, 50, 1421-60.

World Bank Regulation Survey, 2000, 2003, 2008 (Washington: The World Bank). 


\section{TeChNiCAl APPENDIX}

Consider a multinational bank operating in $m$ countries. The multinational has one subsidiary bank in each of its host country $i$ with total assets $A_{i}, A_{i}$ is assumed to be given. The parent bank maximizes the sum of post-tax profits of all its subsidiaries:

$\operatorname{Max} \sum_{i=1}^{m}\left(1-k_{i}\right)\left(1-t_{i}\right) P_{i}-\sum_{i=1}^{m} C_{i}-C_{p}$,

s.t. $P_{i}=l_{i} L_{i}-r B_{i}$,

where $L_{i}$ is subsidiary bank-made loans to borrowers with interest rate $l_{i}$ and $r B_{i}$ is its interest expenses from debt $B_{i}$ with interest rate $r ; C_{i}=\frac{m_{i}\left(r_{E i}\right) A_{i} b_{i}^{2}}{2}$, in which $b_{i}=B_{i} / A_{i}$, and $m_{i}\left(r_{E i}\right)$ is positive and an increasing function of subsidiary bank's capital requirement;

$C_{p}=\frac{g_{p}\left(r_{E p}\right) A_{p}\left(\sum_{i=1}^{m} b_{i} q_{i}\right)^{2}}{2}$, where $g_{p}\left(r_{E p}\right)$ is positive and an increasing function in the capital requirement faced by the parent bank, the parent asset $A_{p}=\sum_{i=1}^{m} A_{i}$, and $q_{i}=\frac{A_{i}}{A_{p}} ; A_{i}=L_{i}+$ $F A=B_{i}+E_{i}$, where $A_{i}$ is given thus $A_{p}$ is given too.

Finally, subsidiary bank outside owners (possessing $k_{i}$ share of the subsidiary bank) requires return $n: \frac{k_{i} P_{i}\left(1-t_{i}\right)}{E_{i}-F A}-1=n$

Substituting constraints into the maximization problem, we can rewrite the problem as below, parent bank maximizes with respect to $L_{i}$ and $B_{i}$ :

$$
\begin{gathered}
\operatorname{Max} \sum_{i=1}^{m}\left(1-t_{i}\right)\left\{L_{i}\left[l_{i}-\frac{1+n}{1-t_{i}}\right]-B_{i}\left[r-\frac{1+n}{1-t_{i}}\right]\right\}-\sum_{i=1}^{m} \frac{m_{i}\left(r_{E i}\right) A_{i} b_{i}^{2}}{2} \\
-\frac{g_{p}\left(r_{E p}\right) A_{p}\left(\sum_{i=1}^{m} b_{i} q_{i}\right)^{2}}{2}
\end{gathered}
$$

From the first order condition for $B_{i}$ :

$$
\begin{aligned}
& -\left(1-t_{i}\right)\left[r-\frac{1+n}{1-t_{i}}\right]-m_{i}\left(r_{E i}\right) b_{i}-g_{p}\left(r_{E p}\right) \sum_{i=1}^{m} b_{i} q_{i}=0 \\
& m_{i}\left(r_{E i}\right) b_{i}=-\left(1-t_{i}\right) r+(1+n)-g_{p}\left(r_{E p}\right) \sum_{i=1}^{m} b_{i} q_{i}
\end{aligned}
$$

Since $\sum_{i=1}^{m} b_{i} q_{i}=b_{i}-\sum_{j \neq i}^{m}\left(b_{i}-b_{j}\right) q_{j}$, we have:

$$
m_{i}\left(r_{E i}\right) b_{i}=t_{i} r-r+(1+n)-g_{p}\left(r_{E p}\right)\left[b_{i}-\sum_{j \neq i}^{m}\left(b_{i}-b_{j}\right) q_{j}\right]
$$




$$
\left(g_{p}\left(r_{E p}\right)+m_{i}\left(r_{E i}\right)\right) b_{i}=t_{i} r-r+(1+n)+g_{p}\left(r_{E p}\right) \sum_{j \neq i}^{m}\left(b_{i}-b_{j}\right) q_{j}
$$

And because $m_{i}\left(r_{E i}\right) b_{i}-m_{j}\left(r_{E j}\right) b_{j}=\left(t_{i}-t_{j}\right) r$

$$
\begin{aligned}
& b_{i}-b_{j}=\frac{\left(t_{i}-t_{j}\right) r}{m_{i}\left(r_{E i}\right)}+b_{j}\left(\frac{m_{j}\left(r_{E j}\right)}{m_{i}\left(r_{E i}\right)}-1\right) \\
& \begin{aligned}
\left(g_{p}\left(r_{E p}\right)+m_{i}\left(r_{E i}\right)\right) b_{i}= & t_{i} r-r+(1+n)+\frac{g_{p}\left(r_{E p}\right) r}{m_{i}\left(r_{E i}\right)} \sum_{j \neq i}^{m}\left(t_{i}-t_{j}\right) q_{j} \\
& \quad+\frac{g_{p}\left(r_{E p}\right)}{m_{i}\left(r_{E i}\right)} \sum_{j \neq i}^{m}\left[b_{j}\left(m_{j}\left(r_{E j}\right)-m_{i}\left(r_{E i}\right)\right)\right] q_{j}
\end{aligned} \\
& b_{i}=\lambda_{0 i}+\lambda_{1 i} t_{i}+\lambda_{2 i} \sum_{j \neq i}^{m}\left(t_{i}-t_{j}\right) q_{j}+\lambda_{3 i} \sum_{j \neq i}^{m}\left[b_{j}\left(m_{j}\left(r_{E j}\right)-m_{i}\left(r_{E i}\right)\right)\right] q_{j}
\end{aligned}
$$

where $\lambda_{0 i}=\frac{1+n-r}{g_{p}\left(r_{E p}\right)+m_{i}\left(r_{E i}\right)}, \lambda_{1 i}=\frac{r}{g_{p}\left(r_{E p}\right)+m_{i}\left(r_{E i}\right)}$,

$$
\lambda_{2 i}=\frac{g_{p}\left(r_{E p}\right) \mathrm{r}}{m_{i}\left(r_{E i}\right)\left[g_{p}\left(r_{E p}\right)+m_{i}\left(r_{E i}\right)\right]} \text {, and } \lambda_{3 i}=\frac{g_{p}\left(r_{E p}\right)}{m_{i}\left(r_{E i}\right)\left[g_{p}\left(r_{E p}\right)+m_{i}\left(r_{E i}\right)\right]}
$$

Because $\lambda_{1 i}$ and $\lambda_{2 i}$ are positive, $b_{i}$ increases with $t_{i}$ and $\sum_{j \neq i}^{m}\left(t_{i}-t_{j}\right) q_{j}$. Moreover, since $m_{i}\left(r_{E i}\right)$ is an increasing function of $r_{E i}$, tax's impacts on $b_{i}$, i.e. $\lambda_{1 i}$ and $\lambda_{2 i}$, are negatively related with $r_{E i}$. 
Figure 1. Bank Leverage Histogram

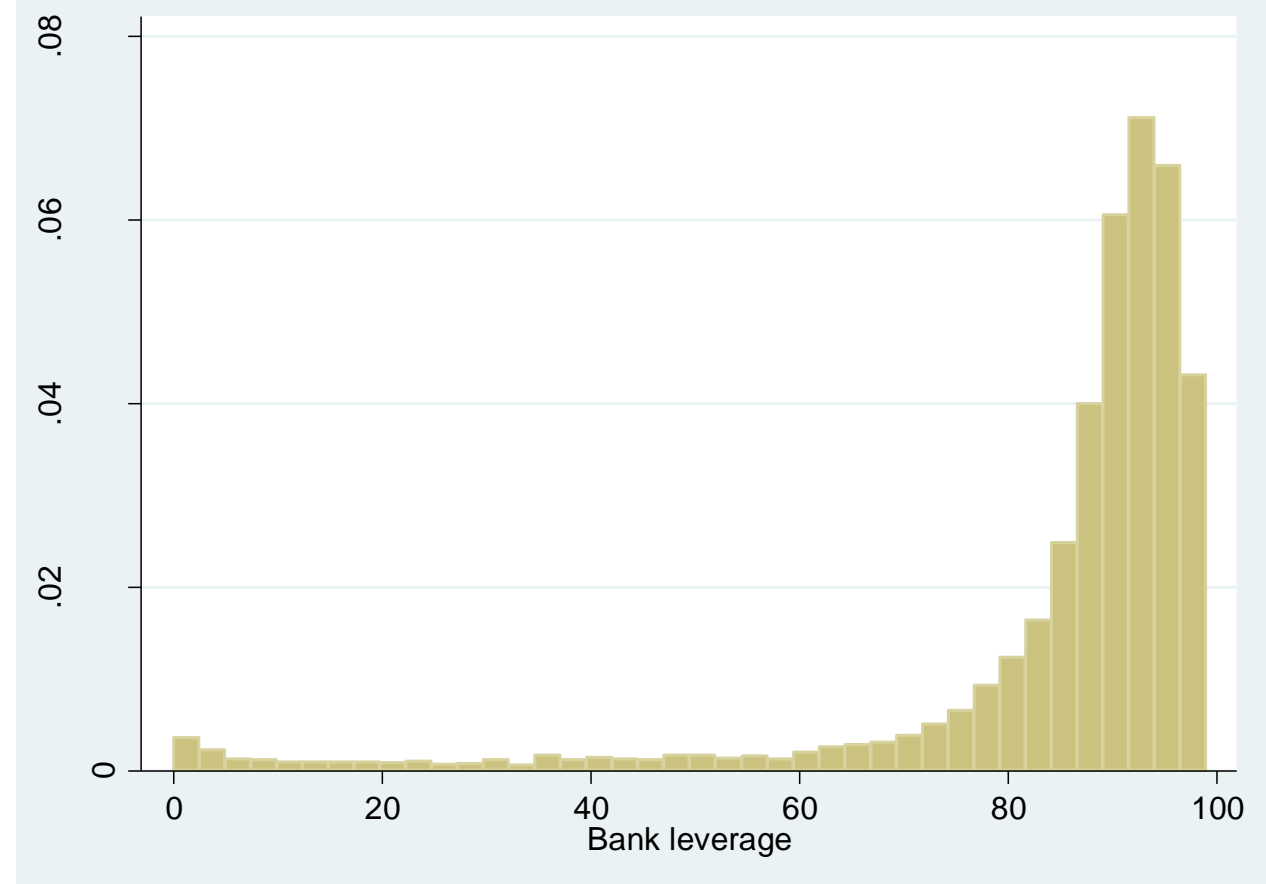

Source: Bankscope and authors' calculations. 


\section{Table 1. Variable Source and Construction}

\begin{tabular}{|c|c|c|}
\hline Variable & Construction & Source \\
\hline Leverage & Total liabilities / Total assets & Bankscope \\
\hline Short-term leverage & Leverage - Long-term funding / Total assets & Bankscope \\
\hline CIT rate & Statutory tax rate & $\begin{array}{l}\text { From a combined source of KPMG Corporate } \\
\text { Tax Survey, OECD Tax Database, and Mintz } \\
\text { and Weichenrieder (2009). }\end{array}$ \\
\hline Effective tax rate & Taxes/ Pre-tax Profit. & Bankscope \\
\hline Capital tightness & (1-leverage ratio)-capital ratio requirement & Bankscope \\
\hline International tax difference & $\begin{aligned} \sum_{j \neq i}^{n}\left(\operatorname{tax}_{i t}-\operatorname{tax}_{j t}\right) q_{j t} & =\operatorname{tax}_{i t}-\sum_{i}^{n} \operatorname{tax}_{i t} q_{i t} \\
\text { and } q_{i t} & =\frac{A_{i t}}{\sum_{n} A_{i t}}\end{aligned}$ & Bankscope, and see CIT rate sources \\
\hline Alt.: Asset-weighted average tax & $\sum_{i}^{n} \operatorname{tax}_{i t} q_{i t}$, and $q_{i t}=\frac{A_{i t}}{\sum_{n} A_{i t}}$ & Bankscope, and see CIT rate sources \\
\hline $\begin{array}{l}\text { Alt.: International tax difference } \\
\text { with time-invariant asset-weights }\end{array}$ & $\begin{array}{c}\sum_{j \neq i}^{n}\left(\operatorname{tax}_{i t}-\operatorname{tax}_{j t}\right) q_{j}=\operatorname{tax}_{i t}-\sum_{i}^{n} \operatorname{tax}_{i t} q_{i} \\
\text { and } q_{i}=\operatorname{mean}\left(\frac{A_{i t}}{\sum_{n} A_{i t}}\right)\end{array}$ & Bankscope \\
\hline $\begin{array}{l}\text { Alt.: International tax difference } \\
\text { with leverage-weights }\end{array}$ & $\begin{array}{c}\sum_{j \neq i}^{n}\left(\operatorname{tax}_{i t}-\operatorname{tax}_{j t}\right) q_{j t}=\operatorname{tax}_{i t}-\sum_{i}^{n} \operatorname{tax}_{i t} q_{i t} \\
\text { and } q_{i t}=\frac{L I A B_{i t}}{\sum_{n} L I A B_{i t}}\end{array}$ & Bankscope \\
\hline Log total assets & $\log ($ total assets $)$ & Bankscope \\
\hline Square log of total assets & {$[\log (\text { total assets })]^{2}$} & Bankscope \\
\hline Profitability & Pre-tax profit / total assets & Bankscope \\
\hline Total assets growth & Annual percentage change of total assets & Bankscope \\
\hline Collateral & (Total security assets + total non-earning assets) / total assets & Bankscope \\
\hline Non-debt tax credit & Total non-interest expenses / total assets & Bankscope \\
\hline GDP growth & Annual percentage change of real GDP & IMF WEO \\
\hline Inflation & Annual percentage change of CPI index & IMF WEO \\
\hline
\end{tabular}

Survey item 3.1 (Minimum total capital-to-assets ratio). The database only has 2000, 2003 and 2008. In our data, 19982000 are the same as $2000 ; 2001-2003$ are the same as 2003; and 2004-2011 are the same as 2008 .

Survey item 8.1 and 8.5 , if a country has an explicit deposit insurance scheme or has any deposits not explicitly covered by deposit insurance at the time of the failure compensated when the bank failed (excluding funds later paid out in liquidation procedures), then this country's deposit insurance observation $=1$; otherwise 0 . The database only has 2000, 2003 and 2008. In our data, 1998-2000 are the same as 2000; 20012003 are the same as 2003; and 2004-2011 are the same as 2008.
World Bank Regulation Survey

World Bank Regulation Survey

Banking Crisis Database (2010 version), Laeven, Luc and Fabian Valencia,

2010, Resolution of Banking Crises: The Good, the Bad, and the Ugly, IMF working paper $10 / 146$. 
Table 2. Summary Statistics

\begin{tabular}{lrrrrrr}
\hline \multicolumn{1}{c}{ Variable } & Obs. & \multicolumn{1}{c}{ Mean } & St. Dev. & \multicolumn{1}{c}{ Min } & Median & Max \\
\hline Leverage (percent) & 3905 & 86.74 & 14.70 & 0.52 & 90.70 & 98.98 \\
Short-term leverage (percent) & 3131 & 80.55 & 17.06 & 0.09 & 85.87 & 98.79 \\
CIT rate (percent) & 3905 & 30.78 & 7.55 & 10.00 & 30.00 & 56.05 \\
International tax difference (percent) & 3905 & -2.13 & 6.53 & -28.04 & -0.04 & 23.65 \\
Alt.: Asset-weighted average tax (percent) & 3905 & 32.91 & 5.74 & 15.07 & 33.72 & 56.05 \\
Alt.: International tax difference with & & & & & & \\
$\quad$ time-invariant asset-weights & & & & & & \\
$\quad$ (percent) & 3905 & -1.79 & 6.15 & -28.56 & -0.13 & 21.87 \\
Alt.: International tax difference with & & & & & & \\
$\quad$ leverage-weights (percent) & 3905 & -2.16 & 6.54 & -28.06 & -0.04 & 23.68 \\
Log total assets & 3905 & 14.86 & 2.28 & 7.94 & 14.58 & 21.82 \\
Square log of total assets & 3905 & 226.14 & 70.60 & 63.08 & 212.72 & 476.09 \\
Profitability (percent) & 3905 & 1.73 & 3.81 & -18.46 & 1.26 & 85.81 \\
Total assets growth (percent) & 3905 & 14.22 & 26.79 & -86.91 & 9.50 & 149.50 \\
Collateral (percent) & 3905 & 27.29 & 20.46 & 0.05 & 23.76 & 98.87 \\
Non-debt tax credit (percent) & 3905 & 4.41 & 10.71 & 0.00 & 2.63 & 321.51 \\
GDP growth (percent) & 3905 & 2.82 & 3.69 & -17.73 & 2.95 & 21.18 \\
Inflation (percent) & 3905 & 4.20 & 5.17 & -1.68 & 2.67 & 61.13 \\
Capital requirement (percent) & 3905 & 8.54 & 1.13 & 7.00 & 8.00 & 12.00 \\
Deposit insurance & 3905 & 0.94 & 0.24 & 0.00 & 1.00 & 1.00 \\
Financial crises & 3905 & 0.22 & 0.42 & 0.00 & 0.00 & 1.00 \\
\hline
\end{tabular}

Source: authors' calculations.

Note: Some observations have lower capital than minimum capital requirement; it is because in our calculation leverage is weighted by total assets instead of risk-weighted assets due to data availability. Definitions of variables are provided in Table 1. 
Table 3. Correlations

\begin{tabular}{|c|c|c|c|c|c|c|c|c|c|}
\hline & Leverage & CIT Rate & $\begin{array}{c}\text { International } \\
\text { Tax } \\
\text { Difference }\end{array}$ & $\begin{array}{c}\text { Alt.: Asset- } \\
\text { weighted } \\
\text { Average } \\
\text { Tax }\end{array}$ & $\begin{array}{c}\text { Alt.: International } \\
\text { Tax Difference } \\
\text { with Time- } \\
\text { Invariant Asset- } \\
\text { Weights } \\
\end{array}$ & $\begin{array}{c}\text { Alt.: } \\
\text { International } \\
\text { Tax Difference } \\
\text { with Leverage- } \\
\text { Weights } \\
\end{array}$ & $\begin{array}{l}\text { Log Total } \\
\text { Assets }\end{array}$ & $\begin{array}{c}\text { Square } \\
\text { Log of } \\
\text { Total } \\
\text { Assets }\end{array}$ & Profitability \\
\hline Leverage & 1 & & & & & & & & \\
\hline CIT rate & -0.0363 & 1 & & & & & & & \\
\hline International tax difference & 0.065 & 0.6764 & 1 & & & & & & \\
\hline Alt.: Asset-weighted average tax & -0.1217 & 0.5454 & -0.2486 & 1 & & & & & \\
\hline $\begin{array}{l}\text { Alt.: International tax difference } \\
\text { with time-invariant asset-weights }\end{array}$ & 0.0728 & 0.7113 & 0.9406 & -0.135 & 1 & & & & \\
\hline $\begin{array}{l}\text { Alt:: International tax difference } \\
\text { with leverage-weights }\end{array}$ & 0.0654 & 0.6773 & 0.9997 & -0.2469 & 0.9391 & 1 & & & \\
\hline Log total assets & 0.4228 & 0.0483 & 0.0557 & 0.0001 & 0.0218 & 0.0589 & 1 & & \\
\hline Square log of total assets & 0.3885 & 0.0657 & 0.0637 & 0.0139 & 0.0297 & 0.0668 & 0.9944 & 1 & \\
\hline Profitability & -0.3574 & 0.0115 & -0.0697 & 0.0944 & -0.0704 & -0.0696 & -0.132 & -0.1326 & 1 \\
\hline Total assets growth & 0.072 & -0.1113 & -0.0728 & -0.0635 & -0.088 & -0.0721 & -0.0465 & -0.051 & 0.0433 \\
\hline Collateral & -0.1256 & 0.0658 & -0.0399 & 0.1319 & -0.053 & -0.0383 & 0.1337 & 0.1474 & 0.1242 \\
\hline Non-debt tax credit & -0.2627 & -0.0237 & -0.0352 & 0.0089 & -0.0339 & -0.0361 & -0.218 & -0.2029 & 0.2067 \\
\hline GDP growth & 0.0145 & -0.0728 & -0.1057 & 0.0245 & -0.1189 & -0.1059 & -0.1308 & -0.1397 & 0.1106 \\
\hline Inflation & -0.0529 & -0.1726 & -0.1036 & -0.109 & -0.1129 & -0.1046 & -0.2062 & -0.2035 & 0.0896 \\
\hline Capital requirement & -0.0498 & -0.3536 & -0.28 & -0.1463 & -0.2842 & -0.2805 & -0.1442 & -0.1494 & 0.0345 \\
\hline Deposit insurance & -0.0181 & 0.0538 & 0.0517 & 0.0119 & 0.066 & 0.0511 & 0.0915 & 0.0978 & -0.0195 \\
\hline \multirow[t]{2}{*}{ Financial crises } & -0.0051 & -0.0417 & 0.0872 & -0.1541 & 0.0548 & 0.0875 & 0.1695 & 0.1788 & -0.0528 \\
\hline & $\begin{array}{c}\text { Total } \\
\text { Assets } \\
\text { Growth } \\
\end{array}$ & Collateral & $\begin{array}{c}\text { Non-Debt Tax } \\
\text { Credit }\end{array}$ & $\begin{array}{c}\text { GDP } \\
\text { Growth }\end{array}$ & Inflation & $\begin{array}{c}\text { Capital } \\
\text { Requirement }\end{array}$ & $\begin{array}{c}\text { Deposit } \\
\text { Insurance }\end{array}$ & $\begin{array}{l}\text { Financial } \\
\text { Crises }\end{array}$ & \\
\hline Total assets growth & 1 & & & & & & & & \\
\hline Collateral & -0.0086 & 1 & & & & & & & \\
\hline Non-debt tax credit & -0.0414 & 0.0208 & 1 & & & & & & \\
\hline GDP growth & 0.2341 & 0.0641 & -0.0331 & 1 & & & & & \\
\hline Inflation & 0.2165 & 0.0489 & 0.0825 & 0.0996 & 1 & & & & \\
\hline Capital requirement & 0.1427 & 0.1016 & 0.0997 & 0.1275 & 0.2637 & 1 & & & \\
\hline Deposit insurance & -0.0241 & -0.041 & 0.0099 & -0.1456 & -0.0657 & -0.0504 & 1 & & \\
\hline Financial crises & -0.107 & -0.0472 & 0.0774 & -0.4095 & -0.0601 & -0.1317 & 0.0902 & 1 & \\
\hline
\end{tabular}

Source: authors' calculations.

Note: Definitions of variables are provided in Table 1. 
Table 4. Number of Banks

\begin{tabular}{|c|c|c|c|c|c|c|c|}
\hline \multirow[b]{2}{*}{ Country } & \multirow{2}{*}{$\begin{array}{l}\text { No. of } \\
\text { Parent } \\
\text { Banks }\end{array}$} & \multicolumn{2}{|c|}{ No. of Sub. Banks } & \multirow[b]{2}{*}{ Country } & \multirow{2}{*}{$\begin{array}{l}\text { No. of } \\
\text { Parent } \\
\text { Banks }\end{array}$} & \multicolumn{2}{|c|}{ No. of Sub. Banks } \\
\hline & & Domestic & Foreign & & & Domestic & Foreign \\
\hline Albania & 0 & 0 & 3 & Kenya & 0 & 0 & 3 \\
\hline Argentina & 0 & 0 & 8 & Korea & 2 & 3 & 0 \\
\hline Armenia & 0 & 0 & 2 & Latvia & 0 & 0 & 4 \\
\hline Australia & 3 & 5 & 0 & Lithuania & 0 & 0 & 3 \\
\hline Austria & 3 & 30 & 16 & Luxembourg & 0 & 0 & 37 \\
\hline Belarus & 0 & 0 & 4 & Malaysia & 0 & 0 & 11 \\
\hline Belgium & 2 & 23 & 7 & Mexico & 1 & 3 & 9 \\
\hline \multicolumn{8}{|l|}{ Bosnia and } \\
\hline Herzegovina & 0 & 0 & 4 & Mozambique & 0 & 0 & 1 \\
\hline Brazil & 3 & 13 & 24 & Netherlands & 1 & 1 & 4 \\
\hline Bulgaria & 0 & 0 & 3 & Nigeria & 0 & 0 & 2 \\
\hline Canada & 4 & 24 & 0 & Norway & 1 & 8 & 5 \\
\hline Chile & 0 & 0 & 4 & Panama & 0 & 0 & 4 \\
\hline China & 3 & 7 & 14 & Paraguay & 0 & 0 & 3 \\
\hline Colombia & 0 & 0 & 6 & Peru & 0 & 0 & 6 \\
\hline Costa Rica & 0 & 0 & 4 & Philippines & 0 & 0 & 1 \\
\hline Croatia & 0 & 0 & 7 & Poland & 0 & 0 & 18 \\
\hline Czech Republic & 0 & 0 & 9 & Portugal & 0 & 0 & 2 \\
\hline Denmark & 1 & 4 & 4 & Romania & 0 & 0 & 7 \\
\hline Egypt & 0 & 0 & 4 & Russia & 3 & 15 & 31 \\
\hline El Salvador & 0 & 0 & 2 & Singapore & 3 & 8 & 0 \\
\hline Estonia & 0 & 0 & 1 & Slovenia & 0 & 0 & 3 \\
\hline Finland & 0 & 0 & 2 & Spain & 3 & 37 & 7 \\
\hline France & 5 & 95 & 47 & Sweden & 4 & 23 & 1 \\
\hline Germany & 7 & 43 & 28 & Switzerland & 2 & 16 & 20 \\
\hline Hong Kong & 2 & 4 & 0 & Thailand & 0 & 0 & 3 \\
\hline Hungary & 0 & 0 & 8 & Tunisia & 0 & 0 & 1 \\
\hline India & 3 & 12 & 7 & Turkey & 4 & 8 & 4 \\
\hline Indonesia & 0 & 0 & 14 & Ukraine & 0 & 0 & 10 \\
\hline Ireland & 0 & 0 & 4 & United Kingdom & 5 & 48 & 36 \\
\hline Italy & 5 & 27 & 0 & United States & 11 & 71 & 60 \\
\hline Jamaica & 0 & 0 & 3 & Uruguay & 0 & 0 & 4 \\
\hline Japan & 5 & 30 & 11 & Venezuela & 0 & 0 & 1 \\
\hline \multirow[t]{2}{*}{ Kazakhstan } & 0 & 0 & 4 & Zambia & 0 & 0 & 3 \\
\hline & & & & TOTAL & 86 & 558 & 558 \\
\hline
\end{tabular}

Source: authors' calculations.

Note: Definitions of variables are provided in Table 1. 
Table 5. Average Financial Leverage and Tax Rates

\begin{tabular}{|c|c|c|c|c|c|c|c|}
\hline Country & Leverage & $\begin{array}{l}\text { CIT } \\
\text { Rate }\end{array}$ & $\begin{array}{l}\text { Intl. } \\
\text { Tax } \\
\text { Diff. }\end{array}$ & Country & Leverage & $\begin{array}{l}\text { CIT } \\
\text { Rate }\end{array}$ & $\begin{array}{c}\text { Intl. } \\
\text { Tax } \\
\text { Diff. }\end{array}$ \\
\hline Albania & 89.0 & 12.9 & -17.6 & Latvia & 91.1 & 16.5 & -9.6 \\
\hline Argentina & 69.3 & 35.0 & 1.3 & Lithuania & 92.1 & 15.9 & -11.6 \\
\hline Armenia & 80.7 & 20.0 & -5.7 & Luxembourg & 93.8 & 31.9 & -1.8 \\
\hline Austria & 90.1 & 28.0 & 0.5 & Malaysia & 87.6 & 27.2 & -5.4 \\
\hline Belarus & 88.1 & 25.5 & 0.1 & Mexico & 87.9 & 31.5 & -2.4 \\
\hline $\begin{array}{l}\text { Belgium } \\
\text { Bosnia and }\end{array}$ & 93.8 & 36.1 & 2.3 & Mozambique & 91.0 & 32.0 & 1.0 \\
\hline Herzegovina & 79.5 & 10.0 & -17.6 & Netherlands & 90.9 & 30.9 & -3.6 \\
\hline Brazil & 81.2 & 34.2 & -0.7 & Nigeria & 79.5 & 30.0 & -3.4 \\
\hline Bulgaria & 86.2 & 12.0 & -13.6 & Norway & 94.0 & 28.0 & 0.3 \\
\hline Chile & 90.5 & 18.5 & -11.0 & Panama & 90.0 & 31.2 & -4.0 \\
\hline China & 87.1 & 25.8 & -4.0 & Paraguay & 87.9 & 20.8 & -13.4 \\
\hline Colombia & 87.1 & 34.2 & 0.9 & Peru & 89.3 & 29.8 & -3.2 \\
\hline Costa Rica & 88.0 & 30.6 & -1.8 & Philippines & 86.3 & 33.0 & 2.6 \\
\hline Croatia & 89.5 & 22.2 & -5.0 & Poland & 89.1 & 19.3 & -11.8 \\
\hline Czech Republic & 92.3 & 24.9 & -3.4 & Portugal & 88.2 & 26.7 & -6.7 \\
\hline Denmark & 86.2 & 26.2 & -3.0 & Romania & 82.6 & 21.1 & -9.3 \\
\hline Egypt & 92.5 & 31.4 & -1.1 & Russia & 82.1 & 22.5 & -6.1 \\
\hline El Salvador & 91.1 & 25.0 & -10.5 & Slovenia & 91.1 & 23.8 & -3.1 \\
\hline Estonia & 89.4 & 22.9 & -5.2 & Spain & 94.9 & 31.4 & -1.0 \\
\hline Finland & 93.7 & 26.0 & 0.1 & Sweden & 88.8 & 28.0 & 3.2 \\
\hline France & 92.1 & 35.8 & 1.2 & Switzerland & 76.5 & 23.2 & -9.7 \\
\hline Germany & 87.2 & 39.0 & 3.8 & Thailand & 79.1 & 30.0 & 5.8 \\
\hline Hungary & 91.3 & 18.2 & -10.0 & Tunisia & 93.6 & 31.7 & 0.9 \\
\hline India & 94.2 & 35.6 & 0.2 & Turkey & 83.1 & 22.4 & -10.6 \\
\hline Indonesia & 84.3 & 29.5 & -2.9 & Ukraine & 88.8 & 25.9 & -6.7 \\
\hline Ireland & 89.2 & 15.0 & -18.4 & United Kingdom & 85.3 & 29.1 & -2.7 \\
\hline Jamaica & 85.4 & 33.3 & 3.0 & United States & 78.7 & 39.3 & 2.4 \\
\hline Japan & 93.0 & 40.2 & 0.6 & Uruguay & 91.0 & 29.8 & -3.7 \\
\hline Kazakhstan & 85.7 & 25.6 & -2.6 & Venezuela & 88.9 & 34.0 & -0.5 \\
\hline \multirow[t]{2}{*}{ Kenya } & 89.5 & 30.5 & -1.5 & Zambia & 88.6 & 35.0 & 3.8 \\
\hline & & & & Total & 86.7 & 30.8 & -2.1 \\
\hline
\end{tabular}

Source: authors' calculations.

Note: Definitions of variables are provided in Table 1. 
Table 6. Baseline Estimation Results

\begin{tabular}{|c|c|c|c|c|}
\hline Variables & $\begin{array}{c}\text { (1) } \\
\text { Only Tax Level }\end{array}$ & $\begin{array}{c}(2) \\
\text { Add Tax } \\
\text { Differences }\end{array}$ & $\begin{array}{c}\text { (3) } \\
\text { Add Country } \\
\text { Variables }\end{array}$ & $\begin{array}{c}(4) \\
\text { Add Country } \\
\text { Variables and } \\
\text { Tax Differences } \\
\end{array}$ \\
\hline $\begin{array}{l}\text { CIT rate } \\
(+)\end{array}$ & $\begin{array}{l}0.2992^{* * *} \\
(6.899)\end{array}$ & $\begin{array}{l}0.2454^{* * *} \\
\quad(5.648)\end{array}$ & $\begin{array}{l}0.2505^{* * *} \\
\quad(5.226)\end{array}$ & $\begin{array}{l}0.1590 * * * \\
\quad(3.329)\end{array}$ \\
\hline $\begin{array}{l}\text { International tax difference } \\
(+)\end{array}$ & & $\begin{array}{l}0.1169 * * * \\
(3.336)\end{array}$ & & $\begin{array}{c}0.1846^{* * * *} \\
(4.919)\end{array}$ \\
\hline $\begin{array}{l}\text { Lag of log of total assets } \\
(+)\end{array}$ & $\begin{array}{c}14.2128 * * * \\
(12.859)\end{array}$ & $\begin{array}{l}14.1763 * * * \\
(12.831)\end{array}$ & $\begin{array}{c}15.0575 * * * \\
(13.105)\end{array}$ & $\begin{array}{c}15.0102 * * * \\
(13.131)\end{array}$ \\
\hline $\begin{array}{l}\text { Lag of square log of total assets } \\
(-)\end{array}$ & $\begin{array}{c}-0.3728 * * * \\
(-10.953)\end{array}$ & $\begin{array}{c}-0.3720 * * * \\
(-10.935)\end{array}$ & $\begin{array}{c}-0.3955^{* * * *} \\
(-11.200)\end{array}$ & $\begin{array}{c}-0.3941 * * * \\
(-11.221)\end{array}$ \\
\hline $\begin{array}{l}\text { Lag of profitability } \\
\text { (?) }\end{array}$ & $\begin{array}{c}-1.1102 * * * \\
(-9.619)\end{array}$ & $\begin{array}{c}-1.0972 * * * \\
(-9.632)\end{array}$ & $\begin{array}{c}-1.0916 * * * \\
(-8.859)\end{array}$ & $\begin{array}{c}-1.0738 * * * \\
(-8.938)\end{array}$ \\
\hline $\begin{array}{l}\text { Lag of total assets growth } \\
\text { (?) }\end{array}$ & $\begin{array}{l}0.0426^{* * *} \\
\quad(5.697)\end{array}$ & $\begin{array}{l}0.0426^{* * *} \\
(5.686)\end{array}$ & $\begin{array}{l}0.0437 * * * \\
(5.357)\end{array}$ & $\begin{array}{l}0.0435 * * * \\
\quad(5.341)\end{array}$ \\
\hline $\begin{array}{l}\text { Lag of Collateral } \\
\text { (?) }\end{array}$ & $\begin{array}{c}-0.0786 * * * \\
(-5.667)\end{array}$ & $\begin{array}{c}-0.0764 * * * \\
(-5.414)\end{array}$ & $\begin{array}{c}-0.0806 * * * \\
(-5.485)\end{array}$ & $\begin{array}{c}-0.0770 * * * \\
(-5.180)\end{array}$ \\
\hline $\begin{array}{l}\text { Lag of non-debt tax credit } \\
(-)\end{array}$ & $\begin{array}{c}-0.0782 * * \\
(-2.529)\end{array}$ & $\begin{array}{c}-0.0780^{* *} \\
(-2.491)\end{array}$ & $\begin{array}{c}-0.0565^{* *} \\
(-2.090)\end{array}$ & $\begin{array}{c}-0.0548^{* *} \\
(-1.993)\end{array}$ \\
\hline $\begin{array}{l}\text { GDP growth } \\
(+)\end{array}$ & & & $\begin{array}{l}0.1650 * * * \\
(3.304)\end{array}$ & $\begin{array}{l}0.1721^{* * * *} \\
\quad(3.416)\end{array}$ \\
\hline $\begin{array}{l}\text { Inflation } \\
(?)\end{array}$ & & & $\begin{array}{l}0.0198 \\
(0.444)\end{array}$ & $\begin{array}{l}0.0229 \\
(0.504)\end{array}$ \\
\hline $\begin{array}{l}\text { Capital requirement } \\
(-)\end{array}$ & & & $\begin{array}{l}0.0346 \\
(0.041)\end{array}$ & $\begin{array}{l}0.1073 \\
(0.126)\end{array}$ \\
\hline $\begin{array}{l}\text { Deposit insurance } \\
(+)\end{array}$ & & & $\begin{array}{l}-1.0984 \\
(-1.255)\end{array}$ & $\begin{array}{l}-1.3074 \\
(-1.482)\end{array}$ \\
\hline $\begin{array}{l}\text { Financial crises } \\
(-)\end{array}$ & & & $\begin{array}{l}-0.8492 \\
(-1.430)\end{array}$ & $\begin{array}{c}-1.1383^{*} \\
(-1.938)\end{array}$ \\
\hline Constant & $\begin{array}{c}-38.1776^{* * *} \\
(-4.088)\end{array}$ & $\begin{array}{c}-44.9677 * * * \\
(-4.629)\end{array}$ & $\begin{array}{c}-42.5385^{* * *} \\
(-3.580)\end{array}$ & $\begin{array}{c}-46.4542^{* * *} \\
(-3.737)\end{array}$ \\
\hline Observations & 4,453 & 4,436 & 3,919 & 3,905 \\
\hline R-squared & 0.467 & 0.468 & 0.469 & 0.472 \\
\hline
\end{tabular}

Note: Robust t-statistics and expected signs are in parentheses; *,**,*** denote significance at the 10,5 , and 1 percent level. All regressions are performed using OLS with host country fixed effects. 
Table 7. Robustness Check Estimation Results: Standard Errors

\begin{tabular}{|c|c|c|c|c|}
\hline Variables & $\begin{array}{c}(5) \\
\text { Cluster } \\
\text { Parent } \\
\end{array}$ & $\begin{array}{c}(6) \\
\text { Cluster } \\
\text { Host } \\
\end{array}$ & $\begin{array}{c}(7) \\
\text { Cluster } \\
\text { Subs. } \\
\end{array}$ & $\begin{array}{c}(8) \\
\text { Driscoll \& } \\
\text { Kraay } \\
\end{array}$ \\
\hline $\begin{array}{l}\text { CIT rate } \\
(+)\end{array}$ & $\begin{array}{l}0.1590 * * \\
(2.551)\end{array}$ & $\begin{array}{c}0.1590 * * * \\
(2.677)\end{array}$ & $\begin{array}{c}0.1590 * * * \\
(2.633)\end{array}$ & $\begin{array}{l}0.1479 * * \\
(2.717)\end{array}$ \\
\hline $\begin{array}{l}\text { International tax difference } \\
(+)\end{array}$ & $\begin{array}{c}0.1846 * * \\
(1.997)\end{array}$ & $\begin{array}{l}0.1846 * * \\
(2.080)\end{array}$ & $\begin{array}{l}0.1846 * * \\
(2.353)\end{array}$ & $\begin{array}{l}0.1774 * \\
(2.073)\end{array}$ \\
\hline $\begin{array}{l}\text { Lag of log of total assets } \\
(+)\end{array}$ & $\begin{array}{l}15.0102 * * * \\
(6.156)\end{array}$ & $\begin{array}{l}15.0102 * * * \\
(5.047)\end{array}$ & $\begin{array}{l}15.0102 * * * \\
(6.093)\end{array}$ & $\begin{array}{c}15.1020 * * * \\
(17.781)\end{array}$ \\
\hline $\begin{array}{l}\text { Lag of square log of total assets } \\
(-)\end{array}$ & $\begin{array}{c}-0.3941 * * * \\
(-5.218)\end{array}$ & $\begin{array}{c}-0.3941 * * * \\
(-4.393)\end{array}$ & $\begin{array}{c}-0.3941 * * * \\
(-5.261)\end{array}$ & $\begin{array}{c}-0.3927 * * * \\
(-16.065)\end{array}$ \\
\hline $\begin{array}{l}\text { Lag of profitability } \\
\text { (?) }\end{array}$ & $\begin{array}{c}-1.0738 * * * \\
(-7.013)\end{array}$ & $\begin{array}{c}-1.0738 * * * \\
(-8.350)\end{array}$ & $\begin{array}{c}-1.0738 * * * \\
(-7.437)\end{array}$ & $\begin{array}{c}-0.7520 * * * \\
(-4.838)\end{array}$ \\
\hline $\begin{array}{l}\text { Lag of total assets growth } \\
\text { (?) }\end{array}$ & $\begin{array}{l}0.0435 * * * \\
\quad(5.751)\end{array}$ & $\begin{array}{c}0.0435 * * * \\
(4.968)\end{array}$ & $\begin{array}{c}0.0435 * * * \\
(5.121)\end{array}$ & $\begin{array}{l}0.0166^{* * * *} \\
(3.557)\end{array}$ \\
\hline $\begin{array}{l}\text { Lag of Collateral } \\
\text { (?) }\end{array}$ & $\begin{array}{c}-0.0770 * * * \\
(-4.594)\end{array}$ & $\begin{array}{c}-0.0770 * * * \\
(-3.288)\end{array}$ & $\begin{array}{c}-0.0770 * * \\
(-2.513)\end{array}$ & $\begin{array}{c}-0.0852 * * * \\
(-4.456)\end{array}$ \\
\hline $\begin{array}{l}\text { Lag of non-debt tax credit } \\
(-)\end{array}$ & $\begin{array}{l}-0.0548 \\
(-1.066)\end{array}$ & $\begin{array}{l}-0.0548 \\
(-1.059)\end{array}$ & $\begin{array}{l}-0.0548 \\
(-1.091)\end{array}$ & $\begin{array}{l}-0.0942 \\
(-1.576)\end{array}$ \\
\hline $\begin{array}{l}\text { GDP growth } \\
(+)\end{array}$ & $\begin{array}{c}0.1721 * * * \\
\quad(4.175)\end{array}$ & $\begin{array}{c}0.1721 * * * \\
(3.926)\end{array}$ & $\begin{array}{c}0.1721 * * * \\
(4.093)\end{array}$ & $\begin{array}{l}0.1408 * * * \\
\quad(3.387)\end{array}$ \\
\hline $\begin{array}{l}\text { Inflation } \\
(?)\end{array}$ & $\begin{array}{l}0.0229 \\
(0.580)\end{array}$ & $\begin{array}{l}0.0229 \\
(0.256)\end{array}$ & $\begin{array}{l}0.0229 \\
(0.463)\end{array}$ & $\begin{array}{l}-0.0273 \\
(-0.306)\end{array}$ \\
\hline $\begin{array}{l}\text { Capital requirement } \\
(-)\end{array}$ & $\begin{array}{l}0.1073 \\
(0.134)\end{array}$ & $\begin{array}{l}0.1073 \\
(0.106)\end{array}$ & $\begin{array}{l}0.1073 \\
(0.126)\end{array}$ & $\begin{array}{l}-0.8087 \\
(-0.821)\end{array}$ \\
\hline $\begin{array}{l}\text { Deposit insurance } \\
(+)\end{array}$ & $\begin{array}{l}-1.3074 \\
(-1.635)\end{array}$ & $\begin{array}{l}-1.3074 \\
(-1.095)\end{array}$ & $\begin{array}{l}-1.3074 \\
(-1.338)\end{array}$ & $\begin{array}{l}-0.5052 \\
(-0.840)\end{array}$ \\
\hline $\begin{array}{l}\text { Financial crises } \\
(-)\end{array}$ & $\begin{array}{l}-1.1383 \\
(-1.620)\end{array}$ & $\begin{array}{l}-1.1383 \\
(-1.190)\end{array}$ & $\begin{array}{c}-1.1383^{*} \\
(-1.693)\end{array}$ & $\begin{array}{l}-1.1186 \\
(-1.583)\end{array}$ \\
\hline Constant & $\begin{array}{c}-46.4542 * * \\
(-2.161)\end{array}$ & $\begin{array}{c}-46.4542 * * \\
(-2.227)\end{array}$ & $\begin{array}{c}-46.4542 * * \\
(-2.104)\end{array}$ & $\begin{array}{c}-42.2655 * * * \\
(-8.071)\end{array}$ \\
\hline Observations & 3,905 & 3,905 & 3,905 & 4,208 \\
\hline R-squared & 0.472 & 0.472 & 0.472 & 0.436 \\
\hline
\end{tabular}

Note: Robust t-statistics and expected signs are in parentheses; *,**,*** denote significance at the 10,5 , and 1 percent level. All regressions are performed using OLS with host country fixed effects. 
Table 8. Robustness Check Estimation Results: Alternatives

\begin{tabular}{|c|c|c|c|c|}
\hline Variables & $\begin{array}{c}\text { (9) } \\
\text { Only Ave. Tax }\end{array}$ & $\begin{array}{c}\text { (10) } \\
\text { Time Invariant }\end{array}$ & $\begin{array}{c}(11) \\
\text { Leverage } \\
\text { Weights }\end{array}$ & $\begin{array}{c}(12) \\
\text { Short Term }\end{array}$ \\
\hline $\begin{array}{l}\text { CIT rate } \\
(+)\end{array}$ & $\begin{array}{l}0.3436^{* * *} \\
(6.183)\end{array}$ & $\begin{array}{c}0.1179 * * \\
(2.479)\end{array}$ & $\begin{array}{c}0.1588 * * * \\
(3.325)\end{array}$ & $\begin{array}{l}0.3074 * * * \\
(3.453)\end{array}$ \\
\hline $\begin{array}{l}\text { International tax difference } \\
(+)\end{array}$ & & & & $\begin{array}{l}0.1763 * * * \\
(2.883)\end{array}$ \\
\hline $\begin{array}{l}\text { Alt.: Asset-weighted average tax } \\
(-)\end{array}$ & $\begin{array}{c}-0.1846 * * * \\
(-4.919)\end{array}$ & & & \\
\hline $\begin{array}{l}\text { Alt.: International tax difference with } \\
\text { time-invariant asset-weights } \\
(+)\end{array}$ & & $\begin{array}{l}0.2469 * * * \\
(5.543)\end{array}$ & & \\
\hline $\begin{array}{l}\text { Alt.: International tax difference with } \\
\text { leverage-weights } \\
(+)\end{array}$ & & & $\begin{array}{c}0.1825^{* * * *} \\
(4.888)\end{array}$ & \\
\hline $\begin{array}{l}\text { Lag of log of total assets } \\
(+)\end{array}$ & $\begin{array}{l}15.0102 * * * \\
(13.131)\end{array}$ & $\begin{array}{l}15.0326 * * * \\
(13.173)\end{array}$ & $\begin{array}{l}14.9911^{* * *} \\
(13.135)\end{array}$ & $\begin{array}{l}10.7582 * * * \\
(8.150)\end{array}$ \\
\hline $\begin{array}{l}\text { Lag of square log of total assets } \\
(-)\end{array}$ & $\begin{array}{c}-0.3941 * * * \\
(-11.221)\end{array}$ & $\begin{array}{l}-0.3945 * * * \\
(-11.251)\end{array}$ & $\begin{array}{c}-0.3935 * * * \\
(-11.224)\end{array}$ & $\begin{array}{c}-0.2893 * * * \\
(-7.065)\end{array}$ \\
\hline $\begin{array}{l}\text { Lag of profitability } \\
\text { (?) }\end{array}$ & $\begin{array}{c}-1.0738 * * * \\
(-8.938)\end{array}$ & $\begin{array}{c}-1.0701 * * * \\
(-8.960)\end{array}$ & $\begin{array}{c}-1.0744 * * * \\
(-8.947)\end{array}$ & $\begin{array}{c}-1.1988 * * * \\
(-5.762)\end{array}$ \\
\hline $\begin{array}{l}\text { Lag of total assets growth } \\
\text { (?) }\end{array}$ & $\begin{array}{c}0.0435^{* * *} \\
(5.341)\end{array}$ & $\begin{array}{l}0.0440 * * * \\
(5.412)\end{array}$ & $\begin{array}{l}0.0436 * * * \\
(5.358)\end{array}$ & $\begin{array}{c}0.0299 * * * \\
(2.647)\end{array}$ \\
\hline $\begin{array}{l}\text { Lag of Collateral } \\
\text { (?) }\end{array}$ & $\begin{array}{c}-0.0770 * * * \\
(-5.180)\end{array}$ & $\begin{array}{c}-0.0747 * * * \\
(-5.008)\end{array}$ & $\begin{array}{c}-0.0767 * * * \\
(-5.171)\end{array}$ & $\begin{array}{c}-0.0488 * * \\
(-2.181)\end{array}$ \\
\hline $\begin{array}{l}\text { Lag of non-debt tax credit } \\
(-)\end{array}$ & $\begin{array}{c}-0.0548 * * \\
(-1.993)\end{array}$ & $\begin{array}{c}-0.0554 * * \\
(-2.021)\end{array}$ & $\begin{array}{c}-0.0548 * * \\
(-1.992)\end{array}$ & $\begin{array}{c}-0.1653 * * * \\
(-3.599)\end{array}$ \\
\hline $\begin{array}{l}\text { GDP growth } \\
(+)\end{array}$ & $\begin{array}{l}0.1721 * * * \\
(3.416)\end{array}$ & $\begin{array}{l}0.1841 * * * \\
(3.641)\end{array}$ & $\begin{array}{l}0.1729 * * * \\
(3.432)\end{array}$ & $\begin{array}{l}0.2174 * * * \\
(2.695)\end{array}$ \\
\hline $\begin{array}{l}\text { Inflation } \\
(?)\end{array}$ & $\begin{array}{l}0.0229 \\
(0.504)\end{array}$ & $\begin{array}{l}0.0255 \\
(0.561)\end{array}$ & $\begin{array}{l}0.0227 \\
(0.500)\end{array}$ & $\begin{array}{l}0.0372 \\
(0.429)\end{array}$ \\
\hline $\begin{array}{l}\text { Capital requirement } \\
(-)\end{array}$ & $\begin{array}{l}0.1073 \\
(0.126)\end{array}$ & $\begin{array}{l}0.1337 \\
(0.158)\end{array}$ & $\begin{array}{l}0.1183 \\
(0.140)\end{array}$ & $\begin{array}{l}-0.1289 \\
(-0.151)\end{array}$ \\
\hline $\begin{array}{l}\text { Deposit insurance } \\
(+)\end{array}$ & $\begin{array}{l}-1.3074 \\
(-1.482)\end{array}$ & $\begin{array}{l}-1.3639 \\
(-1.537)\end{array}$ & $\begin{array}{l}-1.3316 \\
(-1.517)\end{array}$ & $\begin{array}{c}-4.7074 * * * \\
(-3.009)\end{array}$ \\
\hline $\begin{array}{l}\text { Financial crises } \\
(-)\end{array}$ & $\begin{array}{r}-1.1383 * \\
(-1.938)\end{array}$ & $\begin{array}{c}-1.1492 * \\
(-1.947)\end{array}$ & $\begin{array}{l}-1.1396^{*} \\
(-1.942)\end{array}$ & $\begin{array}{c}-2.3441 * * * \\
(-2.734)\end{array}$ \\
\hline Constant & $\begin{array}{c}-46.4542 * * * \\
(-3.737)\end{array}$ & $\begin{array}{c}-39.8849 * * * \\
(-3.373)\end{array}$ & $\begin{array}{c}-40.5278^{* * *} \\
(-3.421)\end{array}$ & $\begin{array}{l}-4.0262 \\
(-0.328)\end{array}$ \\
\hline Observations & 3,905 & 3,919 & 3,919 & 3,131 \\
\hline R-squared & 0.472 & 0.473 & 0.472 & 0.296 \\
\hline
\end{tabular}

Note: Robust t-statistics and expected signs are in parentheses; *,**,*** denotes significance at the 10,5 , and 1 percent level. All regressions are performed using OLS with host country fixed effects. 
Table 9. Robustness Check Estimation Results:

Leverage Skewness and Tax Trend

\begin{tabular}{|c|c|c|}
\hline Variables & $\begin{array}{c}\text { (13) } \\
\text { Quantile }\end{array}$ & $\begin{array}{l}\text { (14) } \\
\text { Trend }\end{array}$ \\
\hline $\begin{array}{l}\text { CIT rate } \\
(+)\end{array}$ & $\begin{array}{l}0.0645 * * * \\
(2.845)\end{array}$ & \\
\hline $\begin{array}{l}\text { Detrended CIT rate } \\
(+)\end{array}$ & & $\begin{array}{l}-0.1089 \\
(-1.106)\end{array}$ \\
\hline International tax difference & $0.0518^{*}$ & $0.2313 * * *$ \\
\hline$(+)$ & $(1.830)$ & $(6.019)$ \\
\hline $\begin{array}{l}\text { Lag of log of total assets } \\
(+)\end{array}$ & $\begin{array}{l}7.4148 * * * \\
(12.063)\end{array}$ & $\begin{array}{c}14.8930 * * * \\
(13.085)\end{array}$ \\
\hline $\begin{array}{l}\text { Lag of square log of total assets } \\
(-)\end{array}$ & $\begin{array}{c}-0.1996 * * * \\
(-11.070)\end{array}$ & $\begin{array}{c}-0.3913 * * * \\
(-11.172)\end{array}$ \\
\hline $\begin{array}{l}\text { Lag of profitability } \\
\text { (?) }\end{array}$ & $\begin{array}{c}-0.7538 * * * \\
(-7.105)\end{array}$ & $\begin{array}{c}-1.0718 * * * \\
(-8.991)\end{array}$ \\
\hline $\begin{array}{l}\text { Lag of total assets growth } \\
\text { (?) }\end{array}$ & $\begin{array}{l}0.0083 * * * \\
(5.007)\end{array}$ & $\begin{array}{l}0.0433 * * * \\
(5.320)\end{array}$ \\
\hline $\begin{array}{l}\text { Lag of Collateral } \\
\text { (?) }\end{array}$ & $\begin{array}{c}-0.0176 * * * \\
(-2.709)\end{array}$ & $\begin{array}{c}-0.0761 * * * \\
(-5.116)\end{array}$ \\
\hline $\begin{array}{l}\text { Lag of non-debt tax credit } \\
(-)\end{array}$ & $\begin{array}{l}-0.1071 \\
(-1.231)\end{array}$ & $\begin{array}{c}-0.0552 * * \\
(-1.999)\end{array}$ \\
\hline $\begin{array}{l}\text { GDP growth } \\
(+)\end{array}$ & $\begin{array}{l}0.0432 \\
(1.588)\end{array}$ & $\begin{array}{l}0.1803 * * * \\
(3.588)\end{array}$ \\
\hline Inflation & -0.0203 & 0.0379 \\
\hline$(?)$ & $(-0.394)$ & $(0.844)$ \\
\hline $\begin{array}{l}\text { Capital requirement } \\
(-)\end{array}$ & $\begin{array}{l}-0.1255 \\
(-0.215)\end{array}$ & $\begin{array}{l}-0.0211 \\
(-0.025)\end{array}$ \\
\hline Deposit insurance & 0.0143 & $-1.8621 * *$ \\
\hline $\begin{array}{l}(+) \\
\text { Financial crises }\end{array}$ & $\begin{array}{c}(0.019) \\
-0.6970 * * *\end{array}$ & $\begin{array}{c}(-2.135) \\
-1.4374 * *\end{array}$ \\
\hline$(-)$ & $(-3.582)$ & $(-2.470)$ \\
\hline Constant & $\begin{array}{l}27.1517 * * * \\
(4.303)\end{array}$ & $\begin{array}{l}-39.4211 * * * \\
(-3.352)\end{array}$ \\
\hline Observations & 4,208 & 3,905 \\
\hline R-squared & - & 0.471 \\
\hline
\end{tabular}


Table 10. Robustness Check Estimation Results: Subsamples

\begin{tabular}{|c|c|c|c|c|}
\hline Variables & $\begin{array}{c}\text { (15) } \\
\text { Unconsolidated }\end{array}$ & $\begin{array}{c}\text { (16) } \\
\text { Profitable }\end{array}$ & $\begin{array}{c}\text { (17) } \\
\text { Adv. Econ }\end{array}$ & $\begin{array}{c}\text { (18) } \\
\text { Before Crisis }\end{array}$ \\
\hline $\begin{array}{l}\text { CIT rate } \\
(+)\end{array}$ & $\begin{array}{l}0.1454 * * \\
(2.315)\end{array}$ & $\begin{array}{c}0.1739 * * * \\
(3.669)\end{array}$ & $\begin{array}{l}0.1210 \\
(1.310)\end{array}$ & $\begin{array}{l}0.1363 * * \\
(2.494)\end{array}$ \\
\hline $\begin{array}{l}\text { International tax difference } \\
(+)\end{array}$ & $\begin{array}{l}0.3219 * * * \\
\quad(5.587)\end{array}$ & $\begin{array}{l}0.1961 * * * \\
\quad(5.012)\end{array}$ & $\begin{array}{l}0.4657 * * * \\
(6.222)\end{array}$ & $\begin{array}{l}0.2248 * * * \\
(5.049)\end{array}$ \\
\hline $\begin{array}{l}\text { Lag of log of total assets } \\
(+)\end{array}$ & $\begin{array}{l}17.3983 * * * \\
(10.538)\end{array}$ & $\begin{array}{c}14.3880 * * * \\
(11.929)\end{array}$ & $\begin{array}{c}18.5307 * * * \\
(13.111)\end{array}$ & $\begin{array}{c}14.4828 * * * \\
(11.538)\end{array}$ \\
\hline $\begin{array}{l}\text { Lag of square log of total assets } \\
(-)\end{array}$ & $\begin{array}{c}-0.4602 * * * \\
(-8.334)\end{array}$ & $\begin{array}{c}-0.3768 * * * \\
(-10.167)\end{array}$ & $\begin{array}{c}-0.4859 * * * \\
(-11.712)\end{array}$ & $\begin{array}{c}-0.3840 * * * \\
(-9.896)\end{array}$ \\
\hline $\begin{array}{l}\text { Lag of profitability } \\
\text { (?) }\end{array}$ & $\begin{array}{c}-1.0525 * * * \\
(-8.168)\end{array}$ & $\begin{array}{c}-1.1727 * * * \\
(-8.123)\end{array}$ & $\begin{array}{c}-1.1777 * * * \\
(-6.907)\end{array}$ & $\begin{array}{c}-1.0836^{* * *} \\
(-7.104)\end{array}$ \\
\hline $\begin{array}{l}\text { Lag of total assets growth } \\
\text { (?) }\end{array}$ & $\begin{array}{c}0.0374 * * * \\
(3.773)\end{array}$ & $\begin{array}{l}0.0408 * * * \\
(4.454)\end{array}$ & $\begin{array}{c}0.0475 * * * \\
(3.120)\end{array}$ & $\begin{array}{l}0.0397 * * * \\
(4.007)\end{array}$ \\
\hline $\begin{array}{l}\text { Lag of Collateral } \\
\text { (?) }\end{array}$ & $\begin{array}{c}-0.0917 * * * \\
(-4.725)\end{array}$ & $\begin{array}{c}-0.0608 * * * \\
(-4.128)\end{array}$ & $\begin{array}{c}-0.0809 * * * \\
(-3.485)\end{array}$ & $\begin{array}{c}-0.0779 * * * \\
(-4.984)\end{array}$ \\
\hline $\begin{array}{l}\text { Lag of non-debt tax credit } \\
(-)\end{array}$ & $\begin{array}{l}-0.0441 \\
(-1.609)\end{array}$ & $\begin{array}{l}-0.0242 \\
(-1.044)\end{array}$ & $\begin{array}{l}-0.0132 \\
(-0.271)\end{array}$ & $\begin{array}{l}-0.1311^{*} \\
(-1.747)\end{array}$ \\
\hline $\begin{array}{l}\text { GDP growth } \\
(+)\end{array}$ & $\begin{array}{l}0.1785^{* *} \\
(2.081)\end{array}$ & $\begin{array}{l}0.1529 * * * \\
(2.755)\end{array}$ & $\begin{array}{l}0.0993 \\
(0.864)\end{array}$ & $\begin{array}{l}0.0188 \\
(0.187)\end{array}$ \\
\hline $\begin{array}{l}\text { Inflation } \\
(?)\end{array}$ & $\begin{array}{l}0.0743 \\
(1.124)\end{array}$ & $\begin{array}{l}0.0433 \\
(1.045)\end{array}$ & $\begin{array}{l}0.9330 * * * \\
(2.828)\end{array}$ & $\begin{array}{c}-0.1047 * * \\
(-1.995)\end{array}$ \\
\hline $\begin{array}{l}\text { Capital requirement } \\
(-)\end{array}$ & $\begin{array}{l}-0.2308 \\
(-0.183)\end{array}$ & $\begin{array}{l}0.6107 \\
(0.758)\end{array}$ & $\begin{array}{c}-8.4484 * * * \\
(-4.030)\end{array}$ & $\begin{array}{l}0.3969 \\
(0.429)\end{array}$ \\
\hline $\begin{array}{l}\text { Deposit insurance } \\
(+)\end{array}$ & $\begin{array}{l}0.7417 \\
(0.552)\end{array}$ & $\begin{array}{l}-1.4056 \\
(-1.506)\end{array}$ & $\begin{array}{l}-2.9782 * \\
(-1.824)\end{array}$ & $\begin{array}{l}-0.8291 \\
(-0.893)\end{array}$ \\
\hline $\begin{array}{l}\text { Financial crises } \\
(-)\end{array}$ & $\begin{array}{l}-1.3515 \\
(-1.606)\end{array}$ & $\begin{array}{l}-0.9438 \\
(-1.543)\end{array}$ & $\begin{array}{c}-2.0520 * * \\
(-2.185)\end{array}$ & $\begin{array}{l}0.2032 \\
(0.272)\end{array}$ \\
\hline Constant & $\begin{array}{c}-59.5663 * * * \\
(-3.688)\end{array}$ & $\begin{array}{c}-45.8512 * * * \\
(-3.789)\end{array}$ & $\begin{array}{l}-1.6650 \\
(-0.096) \\
\end{array}$ & $\begin{array}{c}-37.9602 * * * \\
(-2.933)\end{array}$ \\
\hline Observations & 2,569 & 3,556 & 1,771 & 2,961 \\
\hline R-squared & 0.504 & 0.478 & 0.504 & 0.487 \\
\hline
\end{tabular}

Note: Robust t-statistics and expected signs are in parentheses; *, **, *** denote significance at the 10, 5, and 1 percent level. All regressions are performed using OLS with host country fixed effects. 
Table 11. Estimation Results: Capital Tightness

\begin{tabular}{|c|c|c|}
\hline Variables & $\begin{array}{c}\text { (19) } \\
\text { Abundant Capital }\end{array}$ & $\begin{array}{c}\text { (20) } \\
\text { Tight Capital }\end{array}$ \\
\hline $\begin{array}{l}\text { CIT rate } \\
(+)\end{array}$ & $\begin{array}{l}0.2780^{*} \\
(1.861)\end{array}$ & $\begin{array}{l}0.0545^{* * *} \\
\quad(5.100)\end{array}$ \\
\hline $\begin{array}{l}\text { International tax difference } \\
(+)\end{array}$ & $\begin{array}{l}0.3460 * * * \\
(4.260)\end{array}$ & $\begin{array}{l}-0.0187 * \\
(-1.901)\end{array}$ \\
\hline $\begin{array}{l}\text { Lag of log of total assets } \\
(+)\end{array}$ & $\begin{array}{l}14.1896 * * * \\
(6.416)\end{array}$ & $\begin{array}{c}0.4363^{*} \\
(1.789)\end{array}$ \\
\hline $\begin{array}{l}\text { Lag of square log of total assets } \\
(-)\end{array}$ & $\begin{array}{c}-0.3413 * * * \\
(-4.460)\end{array}$ & $\begin{array}{l}-0.0101 \\
(-1.391)\end{array}$ \\
\hline $\begin{array}{l}\text { Lag of profitability } \\
\text { (?) }\end{array}$ & $\begin{array}{c}-0.7994 * * * \\
(-6.937)\end{array}$ & $\begin{array}{c}-0.2331 * * * \\
(-5.120)\end{array}$ \\
\hline $\begin{array}{l}\text { Lag of total assets growth } \\
\text { (?) }\end{array}$ & $\begin{array}{l}0.0506^{* * * *} \\
(3.512)\end{array}$ & $\begin{array}{l}0.0039 * * \\
(2.289)\end{array}$ \\
\hline $\begin{array}{l}\text { Lag of Collateral } \\
(?)\end{array}$ & $\begin{array}{c}-0.1602 * * * \\
(-5.559)\end{array}$ & $\begin{array}{l}0.0066 * * * \\
(3.253)\end{array}$ \\
\hline $\begin{array}{l}\text { Lag of non-debt tax credit } \\
(-)\end{array}$ & $\begin{array}{l}-0.0143 \\
(-0.473)\end{array}$ & $\begin{array}{c}-0.0733^{* *} \\
(-2.228)\end{array}$ \\
\hline $\begin{array}{l}\text { GDP growth } \\
(+)\end{array}$ & $\begin{array}{l}0.3336 * * * \\
(2.847)\end{array}$ & $\begin{array}{l}0.0112 \\
(0.995)\end{array}$ \\
\hline $\begin{array}{l}\text { Inflation } \\
(?)\end{array}$ & $\begin{array}{l}0.0484 \\
(0.575)\end{array}$ & $\begin{array}{l}0.0248 * * \\
(2.002)\end{array}$ \\
\hline $\begin{array}{l}\text { Capital requirement } \\
(-)\end{array}$ & $\begin{array}{l}0.5059 \\
(0.371)\end{array}$ & $\begin{array}{l}-0.0613 \\
(-0.272)\end{array}$ \\
\hline $\begin{array}{l}\text { Deposit insurance } \\
(+)\end{array}$ & $\begin{array}{l}0.2323 \\
(0.154)\end{array}$ & $\begin{array}{l}0.0484 \\
(0.167)\end{array}$ \\
\hline $\begin{array}{l}\text { Financial crises } \\
(-)\end{array}$ & $\begin{array}{l}0.3287 \\
(0.224)\end{array}$ & $\begin{array}{l}-0.0369 \\
(-0.357)\end{array}$ \\
\hline Constant & $\begin{array}{c}-53.2262 * * * \\
(-2.623)\end{array}$ & $\begin{array}{c}85.1981 * * * \\
(26.591)\end{array}$ \\
\hline Observations & 1,346 & 1,350 \\
\hline R-squared & 0.446 & 0.585 \\
\hline
\end{tabular}

Note: We divide subsidiaries banks into three equal-size groups, banks with most abundant capital, median capital, and tightest capital. Dropping the middle group, we regress on bank leverage using the observations with most abundant capital and tightest capital buffers, respectively. More specifically, capital-abundant banks at each date are those with a ratio of equity/total assets exceeding the minimum capital requirement by 3 percentage points, while capital-tight banks at each date are those with a ratio of equity/total assets less than the minimum capital requirement by 1.2 percentage points. In our sample, it is possible for a bank to have equity ratio less than the minimum capital requirement because equity is weighted by total assets instead of risk-weighted assets due to data availability. Robust tstatistics and expected signs are in parentheses; *, **, *** denote significance at the 10,5 , and 1 percent level. All regressions are performed using OLS with host country fixed effects. 